\title{
PSD-95 Is Essential for Hallucinogen and Atypical Antipsychotic Drug Actions at Serotonin Receptors
}

\author{
Atheir I. Abbas, ${ }^{1 \star}$ Prem N. Yadav, ${ }^{2 \star}$ Wei-Dong Yao, ${ }^{7,8,9,10}$ Margaret I. Arbuckle, ${ }^{11}$ Seth G. N. Grant, ${ }^{11,12}$ Marc G. Caron, ${ }^{7,8,9}$ \\ and Bryan L. Roth $1,2,3,4,5,6$ \\ ${ }^{1}$ Department of Biochemistry, Case Western Reserve University School of Medicine, Cleveland, Ohio 44106, Departments of ${ }^{2} \mathrm{Pharmacology},{ }^{3} \mathrm{Medicinal}$ \\ Chemistry, and ${ }^{4}$ Psychiatry, ${ }^{5}$ Lineberger Cancer Center, and ${ }^{6}$ National Institute of Mental Health Psychoactive Drug Screening Program, University of North \\ Carolina, Chapel Hill, North Carolina 27599, Departments of ${ }^{7}$ Cell Biology, ${ }^{8}$ Medicine, and ${ }^{9}$ Neurobiology, Duke University Medical Center, Durham, North \\ Carolina 27710, ${ }^{10}$ Department of Psychiatry, Division of Neurosciences, New England Primate Research Center, Harvard Medical School, Boston, \\ Massachusetts 02115, ${ }^{11}$ Division of Neuroscience, University of Edinburgh, Edinburgh EH8 9JZ, United Kingdom, and ${ }^{12}$ Genes to Cognition Programme, \\ Wellcome Trust Sanger Institute, Cambridge CB10 1SA, United Kingdom
}

Here, we report that postsynaptic density protein of $95 \mathrm{kDa}$ (PSD-95), a postsynaptic density scaffolding protein, classically conceptualized as being essential for the regulation of ionotropic glutamatergic signaling at the postsynaptic membrane, plays an unanticipated and essential role in mediating the actions of hallucinogens and atypical antipsychotic drugs at 5- $\mathrm{HT}_{2 \mathrm{~A}}$ and $5-\mathrm{HT}_{2 \mathrm{C}}$ serotonergic G-proteincoupled receptors. We show that PSD-95 is crucial for normal 5- $\mathrm{HT}_{2 \mathrm{~A}}$ and 5- $\mathrm{HT}_{2 \mathrm{C}}$ expression in vivo and that PSD-95 maintains normal receptor expression by promoting apical dendritic targeting and stabilizing receptor turnover in vivo. Significantly, $5-\mathrm{HT}_{2 \mathrm{~A}^{-}}$and $5-\mathrm{HT}_{2 \mathrm{C}^{-}}$ mediated downstream signaling is impaired in $P S D-95^{\text {null }}$ mice, and the 5- $\mathrm{HT}_{2 \mathrm{~A}}$-mediated head-twitch response is abnormal. Furthermore, the ability of $5-\mathrm{HT}_{2 \mathrm{~A}}$ inverse agonists to normalize behavioral changes induced by glutamate receptor antagonists is abolished in the absence of PSD-95 in vivo. These results demonstrate that PSD-95, in addition to the well known role it plays in scaffolding macromolecular glutamatergic signaling complexes, profoundly modulates metabotropic 5- $\mathrm{HT}_{2 \mathrm{~A}}$ and 5- $\mathrm{HT}_{2 \mathrm{C}}$ receptor function.

\section{Introduction}

Known hallucinogens include lysergic acid diethylamide (LSD)like hallucinogens such as mescaline, LSD, psilocin, and $N, N$ dimethyltryptamine (Nichols, 2004) and non-LSD-like hallucinogens such as salvinorin A (Roth et al., 2002). 5- $\mathrm{HT}_{2 \mathrm{~A}}$ serotonin receptors, which represent the main site of action of the LSD-type hallucinogens (Glennon et al., 1984), are most heavily expressed in the apical dendrites and soma of pyramidal neurons in cortical layers II, III, V, and VI (Willins et al., 1997; Jakab and GoldmanRakic, 1998), and knockout and tissue-specific rescue studies indicate that cortical 5- $\mathrm{HT}_{2 \mathrm{~A}}$ receptors are the main site of action of hallucinogens (González-Maeso et al., 2007). Moreover, the

\footnotetext{
Received March 5, 2009; revised April 13, 2009; accepted April 23, 2009.

A.I.A., P.N.Y., and B.L.R. were supported by Grants NIMH61887 and U19MH82441 from the National Institute of Mental Health-National Institutes of Health (NIH), and the National Institute of Mental Health Psychoactive Drug Screening Program; B.L.R. received additional support as a National Alliance for Research on Schizophrenia and Depression (NARSAD) Distinguished Investigator. A.I.A. was also supported by the Case Western Reserve University (CWRU) Medical Scientist Training Program and NIH Grant T32 GM007250. W.-D.Y. received funding support from the following: DA021420 (National Institute on Drug Abuse), NS057311 (National Institute of Neurological Disorders and Stroke), RR00168 (New England Primate Research Center). M.G.C. was funded by NIH Grants NS-19576 and MH-73853. M.G.C. is the NARSAD Lattner Foundation Distinguished Investigator. S.G.N.G. is funded by the Wellcome Trust Genes to Cognition Programme. We thank the Gene Expression and Genotyping Core Facility at the Case Comprehensive Cancer Center at CWRU and the Mouse Behavioral Phenotyping Laboratory Core Facility in the Neurodevelopmental Disorders Research Center at University of North Carolina, Chapel Hill. We also thank Dr. Blaine Armbruster for his technical help.

${ }^{*}$ A.I.A. and P.N.Y. contributed equally to this work.

Correspondence should be addressed to Dr. Bryan L. Roth, Department of Pharmacology, University of North Carolina, 4009 Genetics Medicine Building, CB\#7365, Chapel Hill, NC 27599-7365. E-mail: bryan_roth@med.unc.edu. D0l:10.1523/JNEUROSCI.1090-09.2009

Copyright $\odot 2009$ Society for Neuroscience $\quad 0270-6474 / 09 / 297124-13 \$ 15.00 / 0$
}

$5-\mathrm{HT}_{2 \mathrm{~A}}$ inverse agonist property of atypical antipsychotic drugs is thought to be an essential feature of their therapeutic actions (Meltzer et al., 1989; Roth et al., 2004a; Gray and Roth, 2007).

The closely related $5-\mathrm{HT}_{2 \mathrm{C}}$ serotonin receptors are located primarily in choroid plexus, striatum, and hippocampus (Molineaux et al., 1989; Clemett et al., 2000; López-Gimenez et al., 2002). 5- $\mathrm{HT}_{2 \mathrm{C}}$ receptors are unique among G-protein-coupled receptors (GPCRs) in that they are post-transcriptionally edited (Burns et al., 1997), a process which affects constitutive activity (Niswender et al., 1999) and the efficiency of G-protein coupling in a functionally selective manner (Price and Sanders-Bush, 2000; Berg et al., 2001; Urban et al., 2007). A number of drugs targeting $5-\mathrm{HT}_{2 \mathrm{C}}$ receptors have been shown to be efficacious in animal models of schizophrenia, obsessive-compulsive disorder (OCD), depression, and obesity (Dunlop et al., 2005, 2006; Sard et al., 2005; Gray and Roth, 2007; Marquis et al., 2007).

Previous studies by our lab and others have demonstrated that the $5-\mathrm{HT}_{2 \mathrm{~A}}$ and $5-\mathrm{HT}_{2 \mathrm{C}}$ receptors, which are essential for the actions of atypical antipsychotic drugs and LSD-like hallucinogens (Roth et al., 2004a; González-Maeso et al., 2007; Berger et al., 2009), can interact in vitro via a canonical type I postsynaptic density protein of $95 \mathrm{kDa}$ (PSD-95)/Dlg/ZO-1 (PDZ)-binding motif (Bécamel et al., 2002, 2004; Xia et al., 2003a) with PSD-95, a PDZ domain-containing scaffolding protein (Chen et al., 2000; Kim et al., 2006; Nicoll et al., 2006) that is an essential regulator of ionotropic glutamatergic neuronal signaling (Migaud et al., 1998; Sheng and Kim, 2002; Ehrlich and Malinow, 2004; Schluter et al., 2006; Xu et al., 2008). These in vitro data suggest that PSD-95 
A
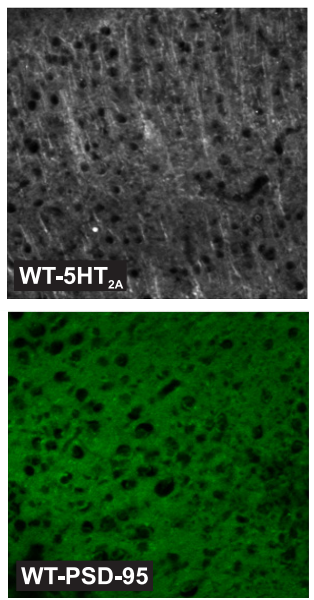

B
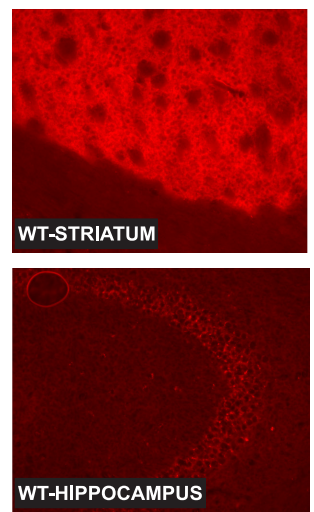

C
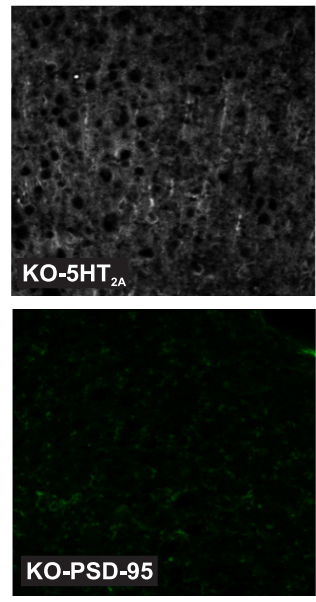

KO-PSD-95
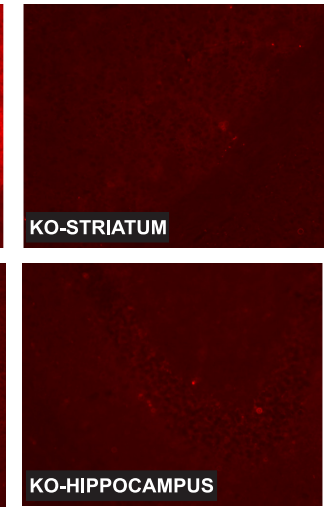

Figure 1. Genetic deletion of PSD-95 results in a selective loss of $5-\mathrm{HT}_{2 \mathrm{~A}}$ and $5-\mathrm{HT}_{2 \mathrm{C}}$ receptors. $A, 5-\mathrm{HT}_{2 \mathrm{~A}}$ and PSD-95 doublelabel immunochemistry in medial prefrontal cortex of PSD-95 $5^{\text {wildtype }}$ and PSD-95 ${ }^{\text {null }}$ mice shows a large reduction in $5-\mathrm{HT}_{2 \mathrm{~A}}$ receptor expression in null mice ( $N=3$ littermate pairs). $B, 5-\mathrm{HT}_{2 C}$ immunochemistry in PSD-95 ${ }^{\text {wildype }}$ and PSD-95 ${ }^{\text {null }}$ striatum and hippocampus reveals that $5-\mathrm{HT}_{2}$ receptor expression is almost completely abolished in the absence of PSD-95 in both striatum and hippocampus ( $N=3$ littermate pairs). $C$, Comparison of $B_{\text {max }}$ estimates for the $5-\mathrm{HT}_{2 \mathrm{~A}}$ receptor $(\mathrm{N}=4$ littermate pairs) and the $5-\mathrm{HT}_{1 \mathrm{~A}}$ receptor ( $N=5$ littermate pairs) in PSD-95 ${ }^{\text {wildtype }}$ and $P S D-95^{\text {null }}$ cortices. $B_{\max }$ estimates were obtained by performing $\left[{ }^{3} \mathrm{H}\right]$-ketanserin $\left(5-\mathrm{HT}_{2 \mathrm{~A}}\right)$ and $\left[{ }^{3} \mathrm{H}\right]-\mathrm{WAY} 100635\left(5-\mathrm{HT}_{1 \mathrm{~A}}\right)$ saturation binding on microdissected and homogenized cortical tissue. Quantitation showed an $\sim 40 \%$ reduction in $5-\mathrm{HT}_{2 \mathrm{~A}}$ expression and no change in $5-\mathrm{HT}_{1 \mathrm{~A}}$ expression in the cortices of PSD-95 ${ }^{\text {null }}$ mice. $D$, Comparison of $B_{\max }$ estimates for the $5-\mathrm{HT}_{2}$ receptor $(N=3$; tissue from 3 animals was pooled for each measurement, for a total of 9 animals, all littermate pairs) and $5-\mathrm{HT}_{1 \mathrm{~A}}$ receptor ( $N=6$ littermate pairs) in PSD-95 wildtype and PSD-95 ${ }^{\text {null }}$ hippocampi. $B_{\max }$ estimates were obtained by performing $\left[{ }^{3} \mathrm{H}\right]$ mesulergine saturation binding in the presence of 100 nm spiperone to block the vast majority of $5-\mathrm{HT}_{2 \mathrm{~A}}$ receptors $\left(5-\mathrm{HT}_{2 \mathrm{C}}\right)$ and [ $\left.{ }^{3} \mathrm{H}\right]-\mathrm{WAY} 100635$ saturation binding $\left(5-\mathrm{HT}_{1 \mathrm{~A}}\right)$. Quantitation showed an almost $70 \%$ reduction in $5-\mathrm{HT}_{2}$ expression and no change in $5-\mathrm{HT}_{1 \mathrm{~A}}$ expression in hippocampus in the absence of PSD-95. All saturation binding was analyzed using nonlinear least squares fitting. $B_{\max }$ data are presented as means $\pm \mathrm{SEM}$; ${ }^{*} p<0.05,{ }^{* *} p<0.01,{ }^{* * *} p<0.001$; one-tailed unpaired $t$ test.

could play a critical role in regulating $5-\mathrm{HT}_{2 \mathrm{~A}}$ and $5-\mathrm{HT}_{2 \mathrm{C}}$ receptors in neurons in vivo, tethering these receptors to the plasma membrane and regulating their trafficking and function. In this study, we show that genetic deletion of PSD-95 leads to profound alterations in $5-\mathrm{HT}_{2 \mathrm{~A}}$ and $5-\mathrm{HT}_{2 \mathrm{C}}$ receptor targeting, expression, and signaling. We also show that these 5-HT receptor-PSD-95 interactions are essential for the normal function of the $5-\mathrm{HT}_{2 \mathrm{~A}}$ and $5-\mathrm{HT}_{2 \mathrm{C}}$ receptors, including their abilities to mediate hallucinogen and atypical antipsychotic drug actions in vivo. Our findings provide new insights into the precise subcellular site(s) of action of hallucinogens and atypical antipsychotic drugs, as well as implicate PSD-95 as an important regulator of metabotropic $5-\mathrm{HT}_{2 \mathrm{~A}}$ and $5-\mathrm{HT}_{2 \mathrm{C}}$ receptor function.

\section{Materials and Methods}

Mice. A detailed description of how the PSD$95^{\text {null }}$ mice were generated will be reported in a future publication (M. I. Arbuckle, N. H. Komiyama, L. H. Forsyth, M. Bence, J. A. Ainge, E. R. Wood, H. J. Carlisle, T. J. O’Dell, and S. G. N. Grant, unpublished observations). Briefly, PSD-95 ${ }^{\text {null }}$ mice were made by deleting the guanylate kinase (GK) domain of the protein. This results in an almost complete absence of PSD-95 mRNA ( $\sim 5.7 \%$ of wild-type levels, as assessed by gene microarray). Previous studies with these mice using two different antibodies raised against epitopes $\mathrm{N}$ terminal to the GK domain of PSD-95 detected no PSD-95 protein whatsoever in the mutant mice (Yao et al., 2004). Our immunochemical studies confirm these findings (Fig. 1A). All experiments were approved by the Institutional Animal Care and Use Committee at Case Western Reserve University or the University of North Carolina, Chapel Hill. Mice were housed under standard conditions- $12 \mathrm{~h}$ light/dark cycle and food and water ad libitum.

Immunochemistry. The following antibodies and dilutions were used: mouse anti-5- $\mathrm{HT}_{2 \mathrm{~A}}$ (PharMingen/BD Biosciences), 1:500 (sections), 1:1000 (neurons); mouse anti-PSD-95 (Upstate Biotechnology), 1:1000; mouse anti5-HT $2 \mathrm{C}$ D-12 (Santa Cruz Biotechnology), 1:500; rabbit anti-microtubule-associated protein 2 (MAP2; Millipore Bioscience Research Reagents), 1:1000; rabbit anti-green fluorescent protein (GFP) A11122 (Invitrogen), 1:1000; rabbit anti-c-fos PC38 (Calbiochem), 1:1000; Alexa Fluor 488 goat anti-mouse or goat antirabbit, and Alexa Fluor 594 goat anti-mouse or goat anti-rabbit (Invitrogen), 1:200. For immunochemistry on brain tissue sections, $P S D$ $95^{\text {wildtype }}$ and $P S D-95^{\text {null }}$ mice were perfused with $4 \%$ paraformaldehyde in $1 \times \mathrm{PBS}$ and their brains harvested and placed overnight in $4 \%$ paraformaldehyde in $1 \times \mathrm{PBS}$ at $4^{\circ} \mathrm{C}$. Over the next night, brains were placed in $30 \%$ sucrose in $1 \times$ PBS until they sank, then frozen on dry ice and stored at $-80^{\circ} \mathrm{C}$. Sections were either freefloating in $1 \times$ PBS (one or two sections per well in a 24-well plate) or thaw-mounted onto coated microscope slides, and they were then permeabilized with $0.3 \%$ Triton in $1 \times$ PBS for 15-20 min. For immunochemistry on cultured cortical neurons, $4 \mathrm{~d}$ in vitro (DIV) neurons were washed twice with $1 \times$ PBS, fixed in $4 \%$ paraformaldehyde in $1 \times$ PBS for $30 \mathrm{~min}$, then washed twice more with $1 \times$ PBS before permeabilizing. Blocking was performed using 5\% milk in $1 \times$ PBS for $1-2 \mathrm{~h}$ Primary antibodies were incubated in $5 \%$ milk in $1 \times$ PBS at room temperature for $2 \mathrm{~h}$ or overnight at $4^{\circ} \mathrm{C}$ while shaking. Sections were then washed three times in $1 \times$ PBS (10 min for each wash). Secondary antibodies were incubated in 5\% milk in $1 \times$ PBS at room temperature for $1 \mathrm{~h}$ in the dark, while shaking. Sections were washed three times in $1 \times$ PBS (10 min for each wash). Free-floating sections and neuronal coverslips were transferred to a microscope slide and mounted for fluorescence microscopic visualization.

Saturation radioligand binding. For saturation binding assays, brain regions were microdissected and frozen on dry ice, then stored at $-80^{\circ} \mathrm{C}$. A Tissue Tearor (BioSpec Products) was used to homogenize tissue (10 s, $15,000 \mathrm{rpm}$ ) in $2 \mathrm{ml}$ of standard binding buffer (SBB; $50 \mathrm{~mm}$ TrisHCl, $\mathrm{pH}$ 
7.4; $10 \mathrm{~mm} \mathrm{MgCl}_{2} ; 0.1 \mathrm{~mm}$ EDTA). Homogenized tissue was spun for 10 min at $26,000 \times g\left(4^{\circ} \mathrm{C}\right)$ and the SBB removed. The pellet was resuspended in $1 \mathrm{ml}$ of SBB and transferred to a $1.7 \mathrm{ml}$ Eppendorf tube, then spun at top speed in a microcentrifuge for $5 \mathrm{~min}$ at $4^{\circ} \mathrm{C}$. The SBB was removed, and the pellet was either used immediately for binding or stored at $-80^{\circ} \mathrm{C}$ until use. Saturation binding assays were performed with the homogenized brain tissue and $\left[{ }^{3} \mathrm{H}\right]$-ketanserin $\left(5-\mathrm{HT}_{2 \mathrm{~A}}\right.$, cortex); $\left[{ }^{3} \mathrm{H}\right]$-mesulergine plus $100 \mathrm{~nm}$ spiperone (5- $\mathrm{HT}_{2 \mathrm{C}}$, hippocampus); or $\left[{ }^{3} \mathrm{H}\right]$-WAY100635 (5-HT $1 \mathrm{~A}$, cortex, hippocampus), then incubated in SBB for $1.5 \mathrm{~h}$. The following $\left[{ }^{3} \mathrm{H}\right]$ concentrations were used: $8 \mathrm{~nm}, 6 \mathrm{nM}$, $4 \mathrm{~nm}, 2 \mathrm{~nm}, 1.5 \mathrm{~nm}, 1.0 \mathrm{~nm}, 0.5 \mathrm{~nm}, 0.25 \mathrm{~nm}\left(5-\mathrm{HT}_{2 \mathrm{~A}}\right.$ and $\left.5-\mathrm{HT}_{2 \mathrm{C}}\right)$, or $2 \mathrm{~nm}$, $1.2 \mathrm{~nm}, 0.8 \mathrm{~nm}, 0.4 \mathrm{~nm}, 0.2 \mathrm{~nm}, 0.1 \mathrm{~nm}, 0.05 \mathrm{~nm}, 0.025 \mathrm{~nm}\left(5-\mathrm{HT}_{1 \mathrm{~A}}\right)$, all in duplicate for total and nonspecific (four reactions at each concentration for each brain sample in which receptor was measured). Nonspecific binding was determined by incubating the reactions with $8 \mu \mathrm{M}$ ritanserin $\left(5-\mathrm{HT}_{2 \mathrm{~A}}\right.$ and $5-\mathrm{HT}_{2 \mathrm{C}}$ ) or $10 \mu \mathrm{M} 5-\mathrm{HT}\left(5-\mathrm{HT}_{1 \mathrm{~A}}\right)$. For 5- $\mathrm{HT}_{2 \mathrm{C}}$ measurements, three samples were pooled for each assay. Bradford protein assays were performed to normalize $B_{\max }$ determinations to the amount of protein in each assay. Reactions were harvested by vacuum filtration through glass filters $(3 \times$ ice-cold $50 \mathrm{~mm}$ Tris, $\mathrm{pH} 7.4$; $\mathrm{pH} 6.9$ at room temperature) and counted by liquid scintillation using a Perkin-Elmer Tri-Carb 2800TR. Microsoft Excel and Graphpad Prism were used for all data analysis.

EEDQ. EEDQ (N-ethoxycarbonyl-1,2-ethoxydihydroquinolone; dissolve EEDQ in $100 \%$ ethanol, than dilute $1: 3$ in saline) was injected intraperitoneally at a dose of $10 \mathrm{mg} / \mathrm{kg}$. Mice were killed at 1, 2, 3, 5, 7, and $13 \mathrm{~d}$ after EEDQ treatment, and the $5-\mathrm{HT}_{2 \mathrm{~A}} B_{\max }$ was measured by saturation binding. Receptor production was assumed to be a zero-order process and receptor trafficking a first-order process (Pinto and Battaglia, 1994). Thus, the equation derived to model receptor recovery was $\left[B_{\max }\right]_{\mathrm{t}}=\left[B_{\max }\right]_{\mathrm{ss}}\left(1-e^{-\mathrm{kt}}\right)$, where $\left[B_{\max }\right]_{\mathrm{t}}$ is the amount of receptor at time $t,\left[B_{\max }\right]_{\mathrm{ss}}$ is the steady state $B_{\max }$ after the receptors have recovered, $k$ is the rate constant for receptor turnover (inverse days, or $\mathrm{d}^{-1}$ ), and $t$ is the time at which $\left[B_{\max }\right]_{\mathrm{t}}$ was measured in days. This model was fit by nonlinear least squares regression to a plot of the average $B_{\max }$ value at each time point.

Quantitative reverse transcription-PCR. Trizol (Invitrogen) was used to extract RNA from microdissected cortical tissue. RNA $(10 \mu \mathrm{g})$ was treated with DNase (DNA-free; Ambion), and $2 \mu \mathrm{g}$ of the DNase-treated RNA was added to a reverse transcription (RT) reaction which was performed using the Superscript III RNase H Reverse Transcriptase kit (Invitrogen) with oligo-(dT) ${ }_{12-18}$ primers (Invitrogen). IQ SYBR Green Supermix (Bio-Rad) was used in a 7300 RT-PCR system (Applied Biosystems) for quantitation. All steps were performed according to manufacturer's instructions.

Microarray experiment. RNA was extracted from microdissected cortical tissue using Trizol (Invitrogen). The gene chip assay was performed by the Gene Expression and Genotyping Core Facility at the Case Comprehensive Cancer Center using the Affymetrix Genechip Mouse Genome 4302.0 Array. Data were analyzed using the Affymetrix Genechip Operating Software, version 1.4.0.036.

5-HT $T_{2 C} m R N A$ editing. Microdissected hippocampal tissue was pooled by genotype and used to generate cDNA as described above. The following primers were used to generate a PCR fragment (containing the edited site) that was 327 base pairs in length that was then inserted into the $B a m \mathrm{HI} / E c o$ RI sites of pcDNA3: forward primer: 5'AAA GGATCC TGT GCT ATT TTC AAC TGC GTC CAT CAT G 3'; reverse primer: 5'AAA GAATTC CGG CGT AGG ACG TAG ATC GTTAAG 3' (Du et al., 2006). Each bacterial colony resulting from transformation of the ligation product represents a transcript. Clones were miniprepped and sequenced to determine the extent of editing for each transcript.

Cortical neuronal cultures. Cortical neurons were prepared from postnatal (P) day 0.5 mouse pups as described previously (Ahlemeyer and Baumgart-Vogt, 2005). Briefly, cortex was microdissected in $\mathrm{Mg}^{2+}$ HBSS under a dissecting microscope and incubated at $37^{\circ} \mathrm{C}$ for $20 \mathrm{~min}$ in neurobasal medium containing $0.1 \%$ papain and $0.02 \%$ BSA. The supernatant was removed and the tissue was then mechanically triturated in neurobasal medium. The supernatant was transferred to a new sterile Eppendorf, leaving the aggregates, and spun down at $200 \times g$ for $10 \mathrm{~min}$.
The supernatant was discarded and the pellet resuspended in preequilibrated (to $37^{\circ} \mathrm{C}$ and $5 \% \mathrm{CO}_{2}$ ) neurobasal medium containing B27 supplement, antibiotics, and $0.5 \mathrm{~mm}$ glutamine, and plated on coverslips coated with low molecular weight poly-L-lysine. Immunochemical experiments were performed at 4-5 DIV.

Lentiviral preparation. PSD-95 was cloned into the Flip, ubiquitin promoter, GFP, and woodchuck hepatitis virus response element (FUGW) lentiviral vector (Lois et al., 2002) by ligating a BclI-digested PSD-95 PCR fragment into the BamHI site $5^{\prime}$ to the GFP (forward primer: $5^{\prime}$-AAA TGA TCA ATG GAC TGT CTC TGT ATA GTG ACA ACC-3'; reverse primer: 5'-AAA TGA TCA GAG TCT CTC TCG GGC TGG GAC CCA$\left.3^{\prime}\right)$. Site-directed mutagenesis was performed to mutate away the stop site that results from the $B c l \mathrm{I}-\mathrm{BamHI}$ ligation at the $3^{\prime}$ end of PSD-95 and shift the reading frame so that PSD-95 is in frame with GFP (sense primer: 5'-GCC CGA GAG AGA CTC TTA TTT CCC CCG GGG GTA CCG GT-3'; antisense primer: 5' -ACC GGT ACC CCC GGG GGA AAT AAG AGT CTC TCT CGG GC-3'). Fugene6 (50 $\mu$ l Fugene6, $10 \mu$ g total DNA per $10 \mathrm{~cm}$ plate) was used to cotransfect HEK293T cells with three plasmids [FUGW/ $88.9 \mathrm{HIV}-1 /$ VSVG (vesicular stomatitis viral glycoprotein)] in a ratio of 3.3/2.5/1. Lentivirus-containing media was collected $48 \mathrm{~h}$ later and filtered through a $0.45 \mu \mathrm{M}$ filter to remove cellular debris. Lentivirus was aliquoted and frozen at $-80^{\circ} \mathrm{C}$ until use. Cortical neurons were infected with 20-50 $\mu$ l GFP or PSD-95 GFP lentivirus at 2 DIV. Immunochemistry was performed at $5 \mathrm{DIV}$.

MK-212-induced c-fos in hippocampus. Mice were injected intraperitoneally with $5 \mathrm{mg} / \mathrm{kg} \mathrm{MK}-212$ in $0.9 \%$ sterile $\mathrm{NaCl}$ or vehicle. Forty-five minutes later, they were perfused with $4 \%$ paraformaldehyde. Frozen sections (Bregma $-1.34 \mathrm{~mm}$ to Bregma $-2.7 \mathrm{~mm}$ ) were thaw mounted onto frosted slides and then used for immunochemistry and subsequent c-fos quantitation.

DOI-induced head-twitch. Mice were injected intraperitoneally with 5 $\mathrm{mg} / \mathrm{kg}$ of DOI [(2,5-dimethoxy-4-iodophenyl)-2-aminopropane]. The number of head-twitches was counted and recorded in 5 min bins for the half hour period immediately after injection. A subset of the $5 \mathrm{mg} / \mathrm{kg}$ injections $(N=7)$ were counted by two observers, one of whom was blinded to the genotype. A comparison of the results produced by the two different observers was not significantly different (data not shown). All the other head-twitch experiments were performed by one blinded observer.

8-OH-DPAT-induced hypothermia. Rectal temperature was measured using the TH-5 Thermalert Monitoring Thermometer (Physitemp Instruments) equipped with a RET-3 probe. The probe was sterilized with $70 \%$ ethanol and covered with vaseline before measuring each mouse's temperature. Mice were then injected intraperitoneally with $5 \mathrm{mg} / \mathrm{kg}$ 8-OH-DPAT [8-hydroxy-2-(di- $n$-propylamino)tetralin], and rectal temperature was measured again 20 min later.

Western blot. DOI or vehicle was injected intraperitoneally, with light restraint to minimize stress effects, and then mice were killed 15 min later by cervical dislocation. Microdissection was performed on ice as quickly as possible. Tissue was homogenized in $400 \mu \mathrm{l}$ of SBB plus protease and phosphatase inhibitors and $5 \%$ glycerol. Tissue was spun for $10 \mathrm{~min}$ at $20-25,000 \times g$. The supernatant, which contains the proteins of interest, was collected and a protein assay performed for quantitation. SDS was added to $25 \mu \mathrm{g}$ of protein boiled for $5 \mathrm{~min}$ to denature and then used for Western blots. The following antibodies were used for Western blot, all at a 1:1000 dilution: rabbit polyclonal p-ERK1/2 (9101L; Cell Signaling Technology), rabbit polyclonal ERK1/2 (9102L; Cell Signaling Technology), p-GSK3 $\beta$ (9331; Cell Signaling Technology), and rabbit monoclonal GSK3 $\beta$ (9315; Cell Signaling Technology).

Prepulse inhibition. All prepulse inhibition (PPI) experiments were performed at the Mouse Behavioral Phenotyping Laboratory Core Facility in the Neurodevelopmental Disorders Research Center at the University of North Carolina, Chapel Hill using the SR-Lab (San Diego Instruments). Briefly, mice were placed in a small, Plexiglas cylinder housed within a large sound-proofed chamber. The cylinder is seated on a piezoelectric transducer which quantifies movement-induced vibrations. The SR-Lab chamber also contains a light, fan, and loudspeaker for acoustic stimuli. Calibration of $70 \mathrm{~dB}$ background sound levels and prepulse acoustic stimuli was performed with a digital sound level meter (San 
Diego Instruments). Each session consisted of a 5 min habituation period followed by 42 trials of seven types-no stimulation, $120 \mathrm{~dB}$ acoustic stimulus (AS50), and five different prepulse stimuli ranging from $4 \mathrm{~dB}$ over back ground (PP74) to $20 \mathrm{~dB}$ over background (PP90). The trial types were performed in six sets of seven, with the trial type order in each set randomized. Intertrial intervals were $10-20 \mathrm{~s}$, with an average interval of $15 \mathrm{~s}$. The AS50 was $40 \mathrm{~ms}$ long, whereas the prepulse stimulus was 20 $\mathrm{ms}$ long and occurred $100 \mathrm{~ms}$ before the onset of the startle stimulus. The sample window for measuring startle amplitude was $65 \mathrm{~ms}$. The formula used to calculate percentage PPI was: ((AS50 - startle after prepulse)/ AS50) $\times 100$. Mice were injected with vehicle, phencyclidine $(\mathrm{PCP})$, or antipsychotic and PCP before being placed in the PPI chamber. When treated with vehicle or PCP, mice were immediately placed in the chamber. When treating with antipsychotic, mice were injected with antipsychotic 15 min before injecting PCP, after which mice were immediately placed in the chamber. There was a 1 week washout period between treatments.

PCP-induced hyperlocomotion. Locomotion was measured in a $1 \mathrm{~h}$ session in an open field chamber $(40 \times 40 \times 30 \mathrm{~cm})$ crossed by a grid of photobeams (VersaMax system; AccuScan Instruments). The mice were injected with vehicle or SR46349B and placed in the chamber for a $20 \mathrm{~min}$ acclimation period, and then they were injected with vehicle or PCP, and locomotion was measured for $1 \mathrm{~h}$. Mice were treated with vehicle, 6.0 $\mathrm{mg} / \mathrm{kg}$ PCP, or $1.0 \mathrm{mg} / \mathrm{kg}$ SR46349B plus $6.0 \mathrm{mg} / \mathrm{kg}$ PCP. Mice were allowed a 1 week washout period between treatments. The number of photobeam breaks was counted during the $60 \mathrm{~min}$ trial in $5 \mathrm{~min}$ bins, and a total distance traveled in centimeters was calculated from the beam break counts.

\section{Results}

PSD-95 is essential for maintaining normal 5- $\mathrm{HT}_{2 \mathrm{~A}}$ and 5$\mathrm{HT}_{2 \mathrm{C}}$ receptor expression in vivo

Previous studies demonstrated that PSD-95 interacts with 5- $\mathrm{HT}_{2 \mathrm{~A}}$ (Xia et al., 2003a,b; Bécamel et al., 2004) and 5- $\mathrm{HT}_{2 \mathrm{C}}$ (Bécamel et al., 2002) receptors in vitro and in vivo. Additionally, ectopic expression of PSD-95 inhibits the agonist-mediated internalization of the 5- $\mathrm{HT}_{2 \mathrm{~A}}$ receptor (Xia et al., 2003a) and promotes desensitization of 5- $\mathrm{HT}_{2 \mathrm{C}}$ receptors (Gavarini et al., 2006) in vitro. Eliminating the type I PDZ ligand motif abrogates both PSD-95 binding and functional activity in vitro (Xia et al., 2003a,b). What, if any, effect PSD-95 might have in vivo is unknown, although we predicted that PSD-95 is responsible for proper targeting and synaptic membrane stabilization of $5-\mathrm{HT}_{2 \mathrm{~A}}$ and $5-\mathrm{HT}_{2 \mathrm{C}}$ serotonin receptors.

To test this prediction, we examined $5-\mathrm{HT}_{2 \mathrm{~A}}$ and $5-\mathrm{HT}_{2 \mathrm{C}}$ receptor expression in PSD-95 ${ }^{\text {wildtype }}$ and PSD-95 ${ }^{\text {null }}$ mice. As seen in Figure $1 A, P S D-95^{\text {null }}$ mice exhibit very little apical dendritic immunofluorescence compared with PSD-95 $5^{\text {wildtype }}$ littermate controls. We also performed saturation binding experiments with $\left[{ }^{3} \mathrm{H}\right]$-ketanserin on microdissected cortices to obtain a quantitative estimate of $5-\mathrm{HT}_{2 \mathrm{~A}}$ receptor levels in null mice (Fig. $1 C)$. We determined that, consistent with our immunohistochemical findings, $P S D-95^{\text {null }}$ mice exhibit a significant reduction in $5-\mathrm{HT}_{2 \mathrm{~A}}$ receptor expression.

As shown in Figure 1B, PSD-95 ${ }^{\text {null }}$ animals displayed even larger decrements of striatal and hippocampal $5-\mathrm{HT}_{2 \mathrm{C}}$ receptors as assessed by a $5-\mathrm{HT}_{2 \mathrm{C}}$-selective antibody. Saturation binding isotherms using $\left[{ }^{3} \mathrm{H}\right]$-mesulergine under conditions which selectively label $5-\mathrm{HT}_{2 \mathrm{C}}$ receptors (see Materials and Methods) demonstrated a $72 \%$ reduction in $5-\mathrm{HT}_{2 \mathrm{C}}$ receptor expression levels in the hippocampus (Fig. 1D).

\section{PSD-95 regulates serotonin receptor turnover}

We next examined several potential mechanisms which might account for the PSD-95-mediated modulation of $5-\mathrm{HT}_{2 \mathrm{~A}}$ and
5- $\mathrm{HT}_{2 \mathrm{C}}$ receptor expression. These included the following: (1) nonspecific effects on the serotonin system; (2) PSD-95mediated regulation of 5-HT receptor transcription and/or a generalized disruption of the machinery essential for neuronal regulation of receptors; (3) PSD-95-mediated alterations in serotonin receptor mRNA editing; and (4) alterations in serotonin receptor turnover. Each of these possibilities will be dealt with in turn.

We first examined the possibility that genetic deletion of PSD-95 leads to generalized serotonergic system dysfunction leading to a reduction in serotonin receptor levels. We examined this first possibility by measuring the expression of a related 5-HT receptor which is also highly expressed in cortex and hippocampus but lacks a PDZ-ligand motif- the $5-\mathrm{HT}_{1 \mathrm{~A}}$ receptor. As our saturation binding experiments using $\left[{ }^{3} \mathrm{H}\right]$-WAY100635 indicate, $5-\mathrm{HT}_{1 \mathrm{~A}}$ expression levels were unchanged in PSD-95 null mice in both cortex (Fig. 1C) and hippocampus (Fig. 1D). These results indicate that genetic deletion of PSD-95 does not lead to a generalized alteration in the serotonergic system.

To examine the unlikely possibility that deleting PSD-95 leads to an alteration in 5-HT receptor gene transcription, we performed quantitative RT-PCR to measure $5-\mathrm{HT}_{2 \mathrm{~A}}$ and $5-\mathrm{HT}_{2 \mathrm{C}}$ receptor mRNA levels. We found that $5-\mathrm{HT}_{2 \mathrm{~A}} \mathrm{mRNA}$ levels are unchanged in cortex (Fig. 2A), and 5- $\mathrm{HT}_{2 \mathrm{C}}$ mRNA levels are unchanged in hippocampus (Fig. $2 A$ ). To further assess the role of PSD-95 in modulating mRNA levels more broadly, or the possibility that compensatory changes in global gene expression occur in null animals and that these compensatory changes cause the observed phenotypes, we performed whole-genome microarray analysis on cDNA prepared from $P S D-95^{\text {wildtype }}$ and $P S D$ $95^{\text {null }}$ cortices. Overall, there were few differences in transcript levels, and only 28 genes ( 27 genes decreased, 1 gene increased) appear to be modulated greater than twofold in the absence of PSD-95-none of which are GPCRs or are expected to modulate the expression of 5-HT receptors (supplemental Table 1, available at www.jneurosci.org as supplemental material). Thus, the whole genome microarray data are more consistent with a role for PSD-95 in post-transcriptional/post-translational regulation of $5-\mathrm{HT}_{2 \mathrm{~A}}$ and $5-\mathrm{HT}_{2 \mathrm{C}}$ receptors.

Interestingly, 6 of the 28 genes, out of $\sim 45,000$ transcripts on the microarray, have previously been reported to be induced after hallucinogen administration (Table 1) (Nichols and SandersBush, 2002; González-Maeso et al., 2003). In one study of transcripts induced by $5-\mathrm{HT}_{2 \mathrm{~A}}$ agonists, only 3 of 13 transcripts shown to be changed by agonist administration were specific to hallucinogenic agonists (González-Maeso et al., 2003). Two of these three genes, egr 2 and per 1 , are downregulated in the absence of PSD-95 according to our microarray data, which is consistent with a possible role of PSD-95 in mediating some $5-\mathrm{HT}_{2 \mathrm{~A}}$ signaling pathways, particularly those related to hallucinogen actions.

The $5-\mathrm{HT}_{2 \mathrm{C}}$ receptor undergoes mRNA editing which modulates its constitutive activity, G-protein coupling efficiency, and expression (Niswender et al., 1999; Price and Sanders-Bush, 2000). It is, therefore, conceivable that changes in $5-\mathrm{HT}_{2 \mathrm{C}}$ receptor expression are secondary to altered editing of $5-\mathrm{HT}_{2 \mathrm{C}} \mathrm{mR}$ NAs. To examine this possibility, we examined RNA editing at all possible sites in $P S D-95^{\text {wildtype }}$ and $P S D-95^{\text {null }}$ hippocampal tissue, and we found that there is no change in the frequency of editing at any of the five sites (Fig. $2 B$ ). Furthermore, there is no significant change in the proportions of 14 of the 15 different isoforms detected in the PSD-95 $5^{\text {null }}$ mice compared with $P S D$ $95^{\text {wildtype }}$ mice (Fig. $2 C, D$ ). An increase in PSD-95 ${ }^{\text {null }}$ mice of 1 isoform out 15 , the valine-serine-isoleucine (VSI) isoform, is in- 
consistent with a role for mRNA editing in downregulating $5-\mathrm{HT}_{2 \mathrm{C}}$ receptors in $P S D$ $95^{\text {null }}$ mice. These findings indicate that neither transcriptional nor posttranscriptional mechanisms (i.e., RNA editing) can account for the large effect that genetic deletion of PSD-95 has on the expression of $5-\mathrm{HT}_{2 \mathrm{~A}}$ and $5-\mathrm{HT}_{2 \mathrm{C}}$ receptors.

Our data clearly point to the fourth prediction that PSD-95 is exerting its effect on the $5-\mathrm{HT}_{2 \mathrm{~A}}$ and $5-\mathrm{HT}_{2 \mathrm{C}}$ receptors by regulating their turnover. Implicit in our hypothesis is that in the absence of PSD95, 5- $\mathrm{HT}_{2 \mathrm{~A}}$ and $5-\mathrm{HT}_{2 \mathrm{C}}$ receptors will have greater access to intracellular trafficking machinery, or will enter alternative trafficking pathways, leading to higher rates of receptor turnover. To assess the rates of receptor turnover in $P S D-95^{\text {wildtype }}$ and $P S D-95^{\text {null }}$ animals, we took advantage of the properties of EEDQ, which binds irreversibly to $5-\mathrm{HT}_{2 \mathrm{~A}}$ receptors (surface and intracellular), occluding them from recognition by their ligands after EEDQ treatment. By treating mice with EEDQ and modeling the rate of receptor recovery over time, one can measure the rate of $5-\mathrm{HT}_{2 \mathrm{~A}}$ receptor turnover in vivo (Pinto and Battaglia, 1994).

For these studies, we injected mice once with EEDQ (10 mg/kg), a dose that achieves $\sim 90 \%$ irreversible blockade of $5-\mathrm{HT}_{2 \mathrm{~A}}$ receptors, and performed saturation binding experiments at different time points after EEDQ treatment to measure the recovery rate of $5-\mathrm{HT}_{2 \mathrm{~A}}$ receptors. If $5-\mathrm{HT}_{2 \mathrm{~A}}$ receptors in null mice have a higher rate of turnover, then the rate constant of recovery (Pinto and Battaglia, 1994) should be higher in these mice. Consistent with this prediction, the modeled receptor recovery in $P S D-95^{\text {wildtype }}$ and PSD-95 ${ }^{\text {null }}$ mice (Fig. $3 A, B$ ) showed that the rate constant, $k\left(d^{-1}\right)$, was substantially higher in null mice. These findings indicate that genetic deletion of PSD-95 accelerates $5-\mathrm{HT}_{2 \mathrm{~A}}$ receptor turnover in vivo. Attempts to perform similar studies with $5-\mathrm{HT}_{2 \mathrm{C}}$ receptors were unsuccessful because of the exceedingly low levels of $5-\mathrm{HT}_{2 \mathrm{C}}$ receptors expressed in PSD-95 $5^{\text {null }}$ mice.

PSD-95 is required for the polarized sorting of $5-\mathrm{HT}_{2 \mathrm{~A}}$ receptors to pyramidal neuron apical dendrites

Another important aspect of our hypothesis focuses on $5-\mathrm{HT}_{2 \mathrm{~A}}$ receptors and the prediction that PSD-95 is crucial for proper targeting to the apical dendrites. Previous studies showed that mutating the PDZ ligand motif prevents dendritic targeting of the $5-\mathrm{HT}_{2 \mathrm{~A}}$ receptor in vitro (Xia et al., 2003b). To determine if PSD-95 is one of the PDZ-domain proteins responsible for the preferential dendritic targeting of $5-\mathrm{HT}_{2 \mathrm{~A}}$ receptors, we examined the ability of $5-\mathrm{HT}_{2 \mathrm{~A}}$ receptors to be sorted to neuronal

${ }^{6}$ Nichols and Sanders-Bush, 2002
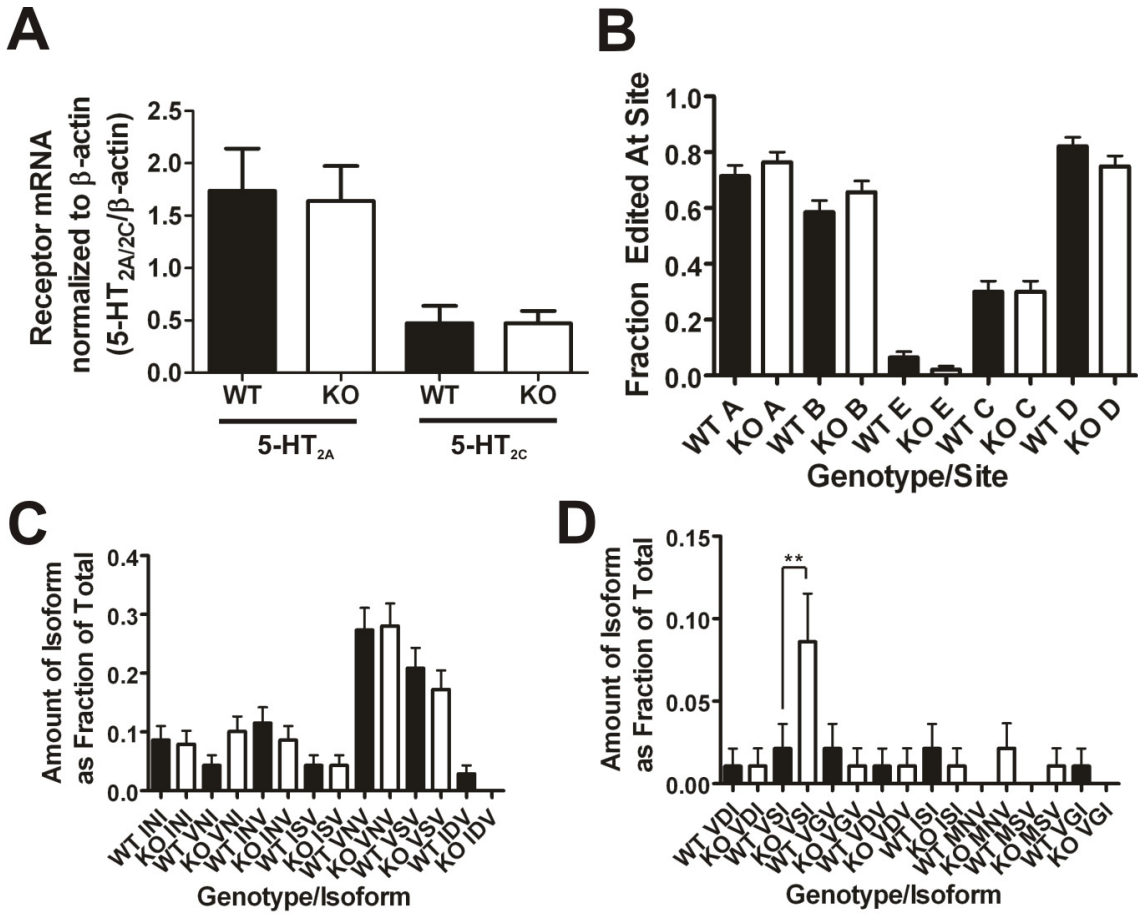

D

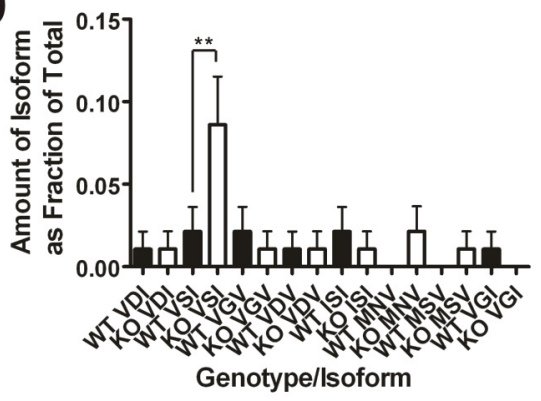

Figure 2. Genetic deletion of PSD-95 does not affect mRNA levels of $5-\mathrm{HT}_{2 \mathrm{~A}}$ and $5-\mathrm{HT}_{2 \mathrm{C}}$ receptors or mRNA editing of the $5-\mathrm{HT} \mathrm{T}_{2 \mathrm{C}}$ receptor. $A$, Cortical $5-\mathrm{HT}_{2 \mathrm{~A}}$ receptor mRNA levels ( $N=4$ littermate pairs; 11 measurements were performed for each animal) and hippocampal $5-\mathrm{HT}_{2}$ receptor mRNA levels $(N=4$ littermate pairs; 5 measurements for each animal) normalized to $\beta$-actin mRNA levels as measured by quantitative RT-PCR. There are no changes in $5-\mathrm{HT}_{2 \mathrm{~A}}$ mRNA levels and no changes in $5-\mathrm{HT}_{2 \mathrm{C}} \mathrm{mRNA}_{\text {levels in }}$ the absence of PSD-95. $B, 5-\mathrm{HT}_{2 C}$ mRNA editing frequencies at five edited sites. The frequency of editing at the five sites is not significantly different in PSD-95 $5^{\text {null }}$ mice. C, D, Frequencies of the different edited isoforms detected (wildtypes, $N=94$; nulls, $N=93$ ). Fifteen isoforms were detected, and 14 of them were not significantly altered in the absence of PSD-95. There is a significant increase in the proportion of the VSI isoform in PSD-95 ${ }^{\text {null }}$ mouse hippocampus. All mRNA editing data are plotted as the frequency expressed as a fraction of the total, \pm the SEM. Normalized mRNA measurements are presented as means \pm SEM; ${ }^{*} p<0.05,{ }^{* *} p<0.01,{ }^{* * *} p<0.001$; one-tailed unpaired $t$ test for the comparison of mRNA levels and one-way ANOVA followed by Newman-Keuls post hoc tests for comparison of the mRNA editing measurements.

Table 1. Genes of interest affected in PSD-95 knock-out mice

\begin{tabular}{lll}
\hline Gene of interest & Alternate names & Downregulation as percentage of wild type \\
\hline Arc $^{b}$ & rg3.1 & 36.6 \\
egr2 $^{a, b}$ & krox20; ngf1b; zfp-25; zfp-6 & 38.6 \\
per1 $^{a}$ & rigui & 42.0 \\
Jun- $^{a}$ & & 46.7 \\
Nr4a1 $^{a}$ & N-10; gfrp; gfrp1; hbr-1; hmr; np10; tr3; nur77; tis1 & 50 \\
Homer1a $^{b, c}$ & & 35.3 \\
\hline
\end{tabular}

Six transcripts that are downregulated in PSD-95 ${ }^{\text {null }}$ mice have been reported to be induced after hallucinogenic drug administration in mice. Most are immediate early genes, which is consistent with a role for PSD-95 in regulating $5-\mathrm{HT}_{2 \mathrm{~A}}$ signaling.

${ }^{a}$ González-Maeso et al., 2003; Yuen et al., 2003.

'The gene previously reported to be upregulated after hallucinogen administration is ania3, a closely related isoform that differs only in the $5^{\prime}$ untranslated region and $a$ few amino acids at the $C$ terminus.

dendrites in cortical neurons prepared from PSD-95 $5^{\text {wildtype }}$ and PSD-95 ${ }^{\text {null }}$ mice.

For these studies, we performed confocal immunofluorescent studies of mouse cortical neurons for $5-\mathrm{HT}_{2 \mathrm{~A}}$ receptors and the dendritic marker MAP2 (Caceres et al., 1984). As Figure 4, $A$ and $B$, illustrates, neurons prepared from $P S D-95^{\text {null }}$ animals exhibit significantly lower $5-\mathrm{HT}_{2 \mathrm{~A}}$ receptor expression in both the neuronal soma and dendrites-a finding consistent with our in vivo data. To examine the impact of PSD-95 on dendritic trafficking, we also calculated a $5-\mathrm{HT}_{2 \mathrm{~A}}$ receptor cell body/dendrite expression $(\mathrm{CB} / \mathrm{D})$ ratio. If dendritic targeting is impaired in PSD-95 $5^{\text {null }}$ neurons, we predicted that the $\mathrm{CB} / \mathrm{D}$ ratio should be higher in 
A PSD-95 WT

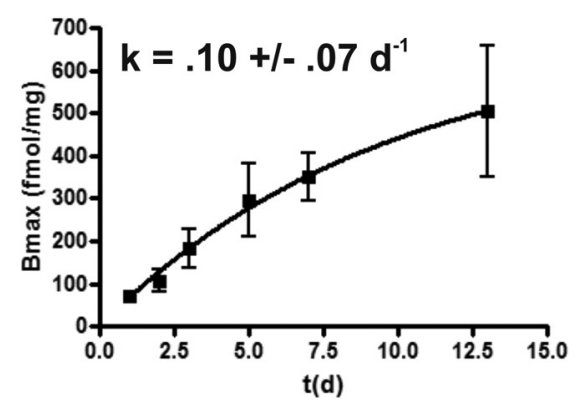

B

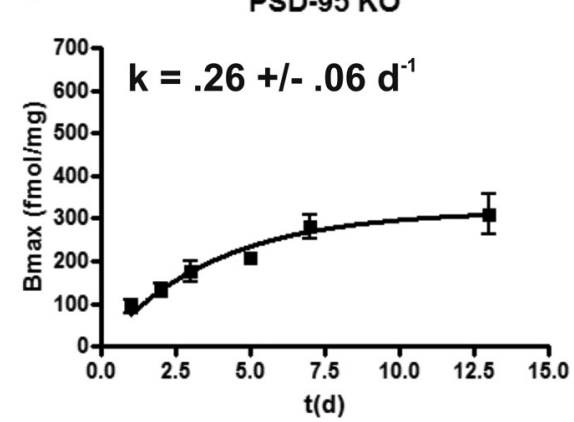

Figure 3. Genetic deletion of PSD-95 leads to an accelerated turnover of $5-\mathrm{HT}_{2 \mathrm{~A}}$ receptor protein. $\boldsymbol{A}$ and $\boldsymbol{B}$ represent fitted curves modeling $5-\mathrm{HT}_{2 \mathrm{~A}}$ receptor turnover in PSD-95 ${ }^{\text {wildtype }}$ and PSD-95 ${ }^{\text {null }}$ mice, respectively $(\mathrm{N}=3-4$ littermate pairs at each data point). Visual inspection shows that steady-state levels for the $5-\mathrm{HT}_{2 \mathrm{~A}}$ receptor are reached sooner in the absence of PSD-95, suggesting accelerated turnover. The higher $k$ in PSD-95 ${ }^{\text {null }}$ cortex indicates a higher rate of receptor turnover in the absence of PSD-95. Rate constant, $k$, is a nonleast squares fitted parameter of an equation modeling receptor recovery (for details, see Materials and Methods), $\pm \mathrm{SEM} ;{ }^{*} p<0.05,{ }^{* *} p<0.01,{ }^{* * *} p<0.001$; one-tailed unpaired $t$ test.

these neurons, as impairment of 5- $\mathrm{HT}_{2 \mathrm{~A}}$ trafficking to dendrites should result in a relative accumulation of receptors in the neuronal cell body. As predicted, Figure $4 B$ confirms that the $C B / D$ ratio is higher in $P S D-95^{\text {null }}$ neurons.

If PSD-95 is essential for $5-\mathrm{HT}_{2 \mathrm{~A}}$ expression and sorting to the dendrites, reintroduction of PSD-95 should increase receptor expression in both the neuronal soma and dendrites. Furthermore, PSD-95 re-expression should decrease the CB/D ratio, representing an increase in dendritic targeting of receptor. To assess the effect of re-expression of PSD-95 on 5- $\mathrm{HT}_{2 \mathrm{~A}}$ expression and targeting, we generated PSD-95-GFP lentivirus and a control GFP lentivirus and infected cortical neuronal cultures prepared from $P S D-95^{\text {null }}$ animals (Fig. 5A). PSD-95-GFP expression led to an $\sim 2$-fold increase in cell body $5-\mathrm{HT}_{2 \mathrm{~A}}$ expression and an $\sim 5$-fold increase in dendritic $5-\mathrm{HT}_{2 \mathrm{~A}}$ expression compared with GFP expression in neurons prepared from the same $P S D-95^{\text {null }}$ animals (Fig. $5 B$ ). Furthermore, as predicted, the $\mathrm{CB} / \mathrm{D}$ ratio is greatly decreased in PSD-95 ${ }^{\text {null }}$ neurons expressing PSD-95-GFP compared with those expressing the control GFP (Fig. 5B).

\section{PSD-95 is required for 5- $\mathrm{HT}_{2 \mathrm{C}}$ signaling in vivo}

Having provided strong evidence that PSD-95 profoundly regulates the expression of $5-\mathrm{HT}_{2 \mathrm{C}}$ receptors, we next examined the consequences of knocking out PSD-95 on $5-\mathrm{HT}_{2 \mathrm{C}}$ function in vivo. It is well established that $c$-fos is an immediate early gene (IEG) which is transcribed after GPCR activation (Lo and Wong, 2006) and which is useful as a general marker of neuronal activity (Chaudhuri, 1997). To examine the consequences of genetic deletion of PSD-95 on signaling downstream of the 5- $\mathrm{HT}_{2 \mathrm{C}}$ receptor and on neural activity, we treated mice with MK-212, a 5- $\mathrm{HT}_{2 \mathrm{C}}$-selective agonist (Thomsen et al., 2008), and assessed induction of c-fos in the hippocampus. Significantly, we found that the number of c-fos-positive cells after MK-212 treatment was greatly reduced in $P S D-95^{\text {null }}$ animals in a number of hippocampal subregions (Fig. 6A, B; supplemental Fig. S1, available at www.jneurosci.org as supplemental material). Our finding that MK-212 induces the largest c-fos response in the dentate gyrus region of the hippocampus is in accordance with previous studies (Campbell and Merchant, 2003). This reduction did not appear to be related to alterations in hippocampal morphology or volume, as cresyl violet staining does not reveal any gross abnormalities in the absence of PSD-95 (supplemental Fig. S2, available at www.jneurosci.org as supplemental material). Furthermore, the thickness of the stained regions [in CA1-CA3, the pyramidal layer; in dentate gyrus (DG), the granular layer] was unchanged in PSD-95 ${ }^{\text {null }}$ mice (supplemental Fig. S2, available at www.jneurosci.org as supplemental material). This decrease in c-fos induction seen in all hippocampal regions measured was highly significant (Fig. 6C) and indicates that genetic deletion of PSD-95 greatly attenuates $5-\mathrm{HT}_{2 \mathrm{C}}$ signaling in vivo.

\section{PSD-95 is essential for hallucinogen actions in vivo}

We also predicted that the alterations in $5-\mathrm{HT}_{2 \mathrm{~A}}$ expression induced by deleting PSD-95 should lead to a reduction in hallucinogen actions in vivo. Although a number of animal models have been proposed for studying hallucinogen action in rodents (Nichols, 2004), head-twitch behavior has been shown to be the most specific for hallucinogenic action in that nonhallucinogenic 5- $\mathrm{HT}_{2 \mathrm{~A}}$ agonists such as lisuride do not induce the behavior (González-Maeso et al., 2007). PSD-95 ${ }^{\text {wildtype }}$ and $P S D$ $95^{\text {null }}$ mice were injected with a $5 \mathrm{mg} / \mathrm{kg}$ dose of the prototypical $5-\mathrm{HT}_{2 \mathrm{~A}}$ hallucinogen 1-(4-iodo-2,5-dimethoxyphenyl)propan2 -amine hydrochloride (Imamura et al., 2002). We found that there was a large and significant decrease in DOI-induced headtwitch in PSD-95 ${ }^{\text {null }}$ animals compared with PSD-95 ${ }^{\text {wildtype }}$ animals (Fig. 7A). Head twitches are virtually nonexistent in both $P S D-95^{\text {wildtype }}$ and $P S D-95^{\text {null }}$ animals after saline treatment $(0-2$ per $30 \mathrm{~min}$; data not shown). In contrast, 8-OH-DPAT, which is known to induce hypothermia via agonist action at $5-\mathrm{HT}_{1 \mathrm{~A}}$ receptors in the CNS (Martin et al., 1992), leads to the same decrease in temperature in both $P S D-95^{\text {wildtype }}$ and $P S D-95^{\text {null }}$ mice (Fig. 7A). Together, the findings suggest that PSD-95 selectively affects behaviors mediated by $5-\mathrm{HT}_{2 \mathrm{~A}}$ receptors.

Given the reduction in DOI-induced head-twitch seen in the absence of PSD-95 in vivo, we also predicted that $5-\mathrm{HT}_{2 \mathrm{~A}}-$ mediated signaling would be reduced or absent in PSD-95 ${ }^{\text {null }}$ mice. The $5-\mathrm{HT}_{2 \mathrm{~A}}$ receptor has been shown to signal through a large number of canonical (phospholipase $\mathrm{C} \beta$ ) and noncanonical (phospholipase $\mathrm{A}_{2}$, phospholipase $\mathrm{D}$, etc.) pathways (Nichols, 2004). The evidence thus far suggests that hallucinogen action is not correlated with canonical signaling pathways, since both hallucinogenic and nonhallucinogenic agonists at the $5-\mathrm{HT}_{2 \mathrm{~A}}$ receptor activate those pathways with similar potencies (Nichols, 2004). $5-\mathrm{HT}_{2 \mathrm{~A}}$ agonists have been shown to activate ERK1/2 via a number of different mechanisms (Hershenson et al., 1995; Greene et al., 2000; Quinn et al., 2002; Göoz et al., 2006), and $5-\mathrm{HT}_{2 \mathrm{~A}}$ agonists also lead to Akt activation (i.e., Akt phosphorylation) (Johnson-Farley et al., 2005). Phosphorylation of Akt leads to phosphorylation of GSK $3 \beta$, which renders that protein inactive (Beaulieu et al., 2008). Accordingly, we predicted that the induction of phospho-ERK1/2 (pERK1/2) and phospho-GSK3 $\beta$ $(\mathrm{p}$-GSK3 $\beta)$ after treatment with DOI $(5 \mathrm{mg} / \mathrm{kg})$ would be reduced or absent in PSD-95 ${ }^{\text {null }}$ mice (Li et al., 2004; Schmid et al., 2008). Consistent with our prediction, we found that DOI was unable to induce pERK1/2 or pGSK3 $\beta$ in PSD-95 ${ }^{\text {null }}$ mice (Fig. $7 B-D$ ). Thus, our evidence suggests that PSD-95 plays an important role in mediating $5-\mathrm{HT}_{2 \mathrm{~A}}$ downstream signaling, and its absence results in signaling and behavioral abnormalities. 
Deletion of PSD-95 renders atypical antipsychotics ineffective

It has been recently demonstrated that synaptic and behavioral measures of dopamine-mediated synaptic plasticity are also altered by genetic deletion of PSD-95 (Yao et al., 2004). We thus hypothesized that the prototypical, gold standard atypical antipsychotic drug clozapine, whose actions are mediated via inverse agonism at $5-\mathrm{HT}_{2 \mathrm{~A}}$ and $5-\mathrm{HT}_{2 \mathrm{C}}$ receptors (Meltzer et al., 1989; Rauser et al., 2001) and by weak $\mathrm{D}_{2} / \mathrm{D}_{3} / \mathrm{D}_{4}$-dopamine antagonism (Roth et al., 2004b), would have an altered activity in PSD-95 ${ }^{\text {null }}$ mice. In this regard, the PCP-induced disruption of PPI is a well accepted pharmacological model of schizophrenia (Geyer et al., 2001; Linn and Javitt, 2001). Importantly, clozapine preferentially normalizes PCP-induced disruption of PPI in both rodents and monkeys, whereas typical antipsychotics like haloperidol have little to no effect (Geyer et al., 2001; Linn et al., 2003). As all the published evidence suggests that $5-\mathrm{HT}_{2 \mathrm{~A}}$ receptors are important in mediating clozapine's reversal of the PCP-induced disruption of PPI (Yamada et al., 1999), we predicted that clozapine would exhibit an altered ability to inhibit PCP-induced disruption of PPI in PSD-95 ${ }^{\text {null }}$ mice.

To test this prediction, we injected littermate pairs of PSD-95 $5^{\text {wildtype }}$ and PSD$95^{\text {null }}$ mice with vehicle, PCP, or clozapine plus PCP, followed by PPI assessment. PCP significantly disrupted PPI at all prepulse levels in PSD-95 $5^{\text {wildtype }}$ mice and at two of the four prepulse levels in $P S D$ $95^{\text {null }}$ mice (Fig. 8 A; supplemental Fig. S3, available at www.jneurosci.org as supplemental material). Clozapine normalized the PCP-induced deficit of PPI in PSD$95^{\text {wildtype }}$ mice while having no significant effect in PSD-95 ${ }^{\text {null }}$ mice. As a control, we also measured startle response and found no significant effect of genotype on startle response (AS50) with and without drug treatments (supplemental Fig. S3, available at www.jneurosci.org as supplemental material), and clozapine treatment alone had no effect on PPI compared with vehicle-treated mice (Fig. $8 \mathrm{~B}$ ). Thus, ge-

netic deletion of PSD-95 abolishes the antipsychotic-like actions of clozapine.

Although the actions of clozapine in NMDA-antagonistbased psychosis models such as PCP-induced disruption of PPI are known to be $5-\mathrm{HT}_{2 \mathrm{~A}}$-mediated, clozapine is nonetheless a pharmacologically "dirty" drug, with a high affinity for a number of other receptors (Roth et al., 2004a). To more firmly establish that $5-\mathrm{HT}_{2 \mathrm{~A}}$ dysfunction is responsible for the abnormal antipsychotic-like efficacy seen in the aforementioned clozapine experiment, we used two selective antagonists of the $5-\mathrm{HT}_{2 \mathrm{~A}}$ receptor, M100907 and SR46349B, which have been shown to be
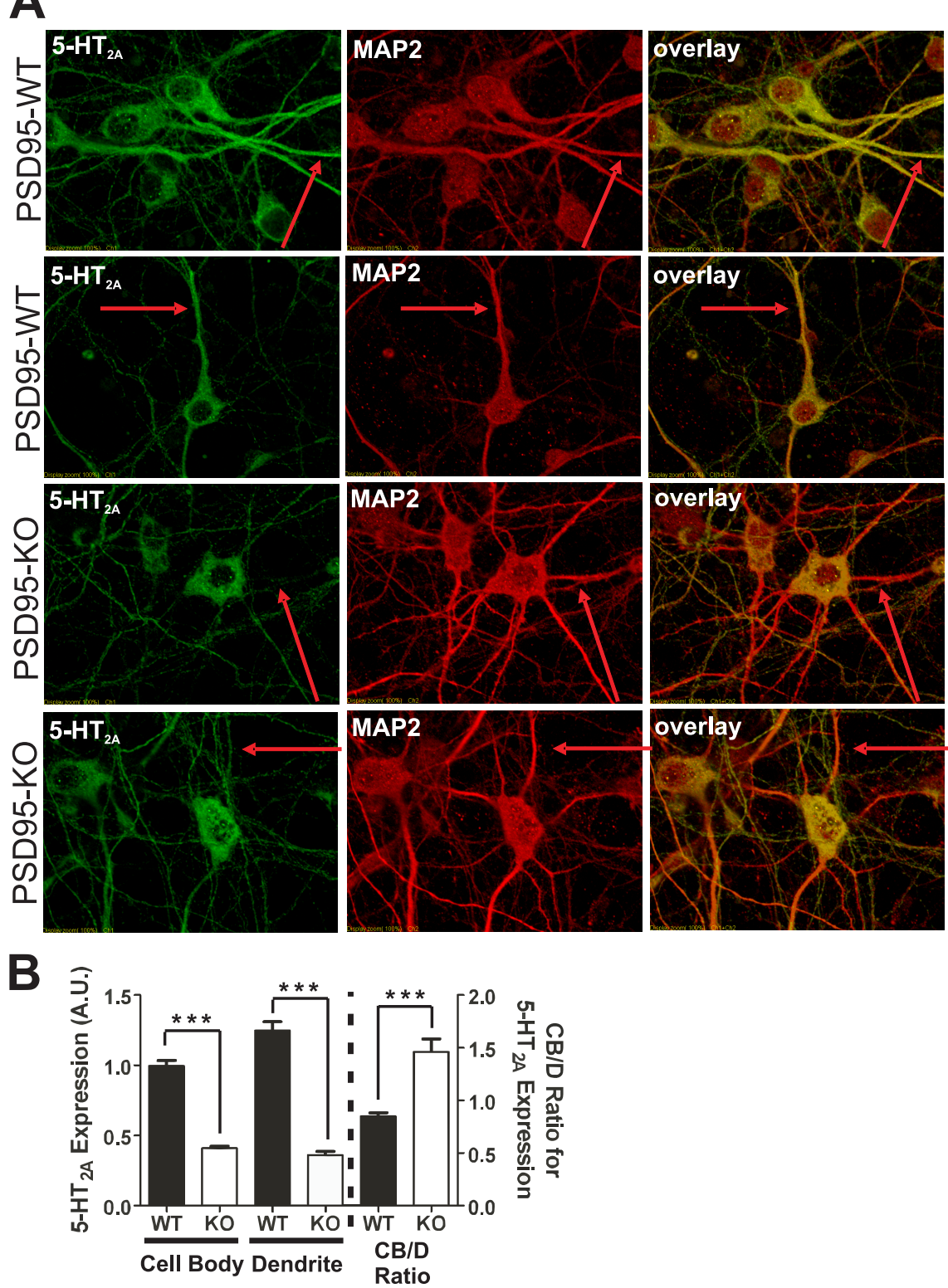

Figure 4. $\quad 5-\mathrm{HT}_{2 \mathrm{~A}}$ receptor expression and dendritic targeting is attenuated in neurons prepared from PSD-95 $5^{\text {null }}$ mice. $\boldsymbol{A}$, Representative images of double-label immunochemistry performed on P0.5 cortical neurons of PSD-95 ${ }^{\text {wildtype }}$ and PSD-95 ${ }^{\text {null }}$ mice. The red arrows highlight the same dendritic process in all three images of each neuron. MAP2-positive dendrites display reduced $5-\mathrm{HT}_{2 \mathrm{~A}}$ receptor expression in the absence of PSD-95. $B$, Comparison of 5- $\mathrm{HT}_{2 \mathrm{~A}}$ receptor expression, normalized to MAP2 expression, in cell bodies and dendrites, and CB/D expression ratio, in PSD-95 $5^{\text {wildype }}$ and PSD-95 ${ }^{\text {null }}$ neurons. Quantitation of $5-\mathrm{HT}_{2 \mathrm{~A}}$ receptors shows that in PSD-95 ${ }^{\text {null }}$ neurons, expression is dramatically reduced in both neuronal soma and dendrites. The increase in the CB/D ratio in PSD-95 ${ }^{\text {null }}$ neurons suggests an impairment in dendritic targeting in the absence of PSD-95. $N=3$ littermate pairs, 17 neurons from each animal, for a total of 51 neurons measured per genotype. Data are presented as the mean \pm the SEM; ${ }^{*} p<0.05,{ }^{* *} p<0.01,{ }^{* * *} p<0.001$; one-tailed unpaired $t$ test.

effective in NMDA antagonist-based animal models of psychosis (Varty et al., 1999) and in clinical studies of schizophrenic patients (Meltzer et al., 2004). If the impaired efficacy of clozapine is because of $5-\mathrm{HT}_{2 \mathrm{~A}}$ dysfunction, then $5-\mathrm{HT}_{2 \mathrm{~A}}$ antagonists should be ineffective as antipsychotics in multiple psychosis models. In this experiment, PCP significantly disrupted PPI at 4 and $8 \mathrm{~dB}$ in both PSD-95 ${ }^{\text {wildtype }}$ and PSD-95 ${ }^{\text {null }}$ mice (Fig. $8 C$ ). As predicted, pretreatment with M100907 (0.5 mg/kg) or SR46349B (1 mg/kg) normalized PCP-induced disruption of PPI in PSD-95 wildtype mice only, having no effect in PSD-95 ${ }^{\text {null }}$ mice (Fig. $8 C$ ). To provide further evidence that antipsychotic-like efficacy medi- 
A
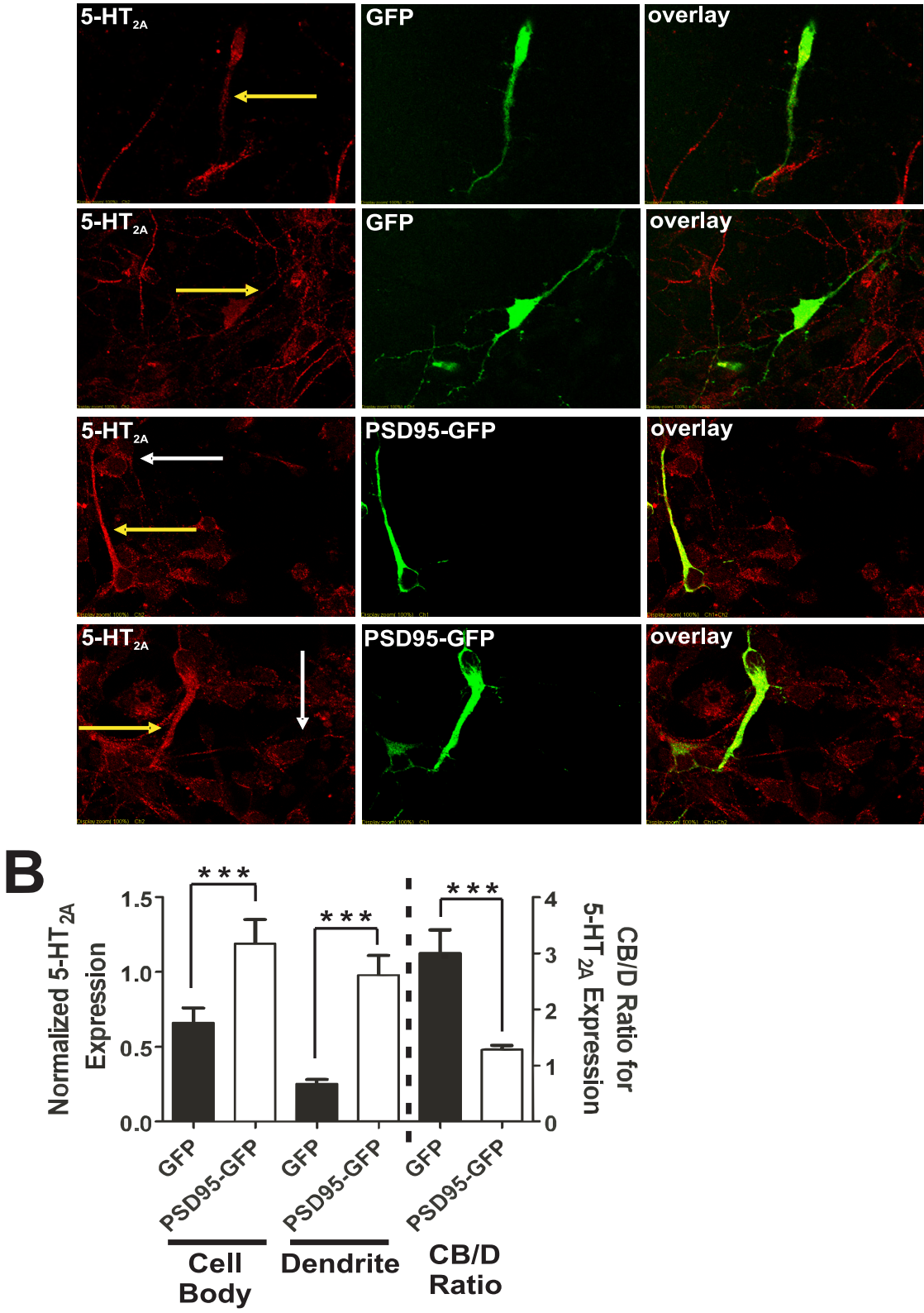

Figure 5. Reintroduction of PSD-95 rescues $5-\mathrm{HT}_{2 \mathrm{~A}}$ receptor expression and trafficking deficits in PSD-95 ${ }^{\text {null }}$ cortical neurons in vitro. $\boldsymbol{A}$, Representative images of double-label immunochemistry performed on P0.5 cortical neurons of PSD-95 ${ }^{\text {null }}$ mice infected with either GFP lentivirus (top 2 rows of panels) or PSD-95-GFP lentivirus (bottom 2 rows of panels). PSD-95 null neurons from each animal were plated in two wells, one for GFP lentiviral infection and the other for PSD-95-GFP lentiviral infection. The yellow arrows highlight dendritic 5- $\mathrm{HT}_{2 \mathrm{~A}}$ receptor expression in an infected neuron. White arrows highlight 5-HT $2 \mathrm{~A}$ receptor expression in an uninfected neuron. GFP-infected neurons display low overall 5- $\mathrm{HT}_{2 \mathrm{~A}}$ expression and low dendritic targeting. In contrast, PSD-95-GFP-infected neurons display a dramatic increase in overall $5-\mathrm{HT}_{2 \mathrm{~A}}$ receptor expression and substantially more receptor appears to be targeted to the dendritic compartment, both compared with control GFP-infected neurons and compared with uninfected neurons in the same field. $B$, Comparison of $5-\mathrm{HT}_{2 \mathrm{~A}}$ receptor expression in cell bodies and dendrites and the CB/D ratio in GFP-and PSD-95-GFP-infected PSD-95 ${ }^{\text {null }}$ neurons. Expression is normalized to GFP or PSD-95-GFP. PSD-95-GFP leads to substantial rescue of 5- $\mathrm{HT}_{2 \mathrm{~A}}$ receptor expression compared with GFP-infected control neurons. PSD-95-GFP addback leads to a significant reduction in the CB/D ratio compared with GFP-expressing control neurons, suggesting that PSD-95-GFP is rescuing dendritic targeting of 5- $\mathrm{HT}_{2 \mathrm{~A}}$ receptor expression. $\mathrm{N}=3$ animals for each animal/lentivirus, and 10 infected neurons from each animal/lentivirus were measured ( 60 neurons total). Data are presented as the mean \pm the SEM; ${ }^{*} p<0.05$, ${ }^{* *} p<0.01,{ }^{* * *} p<0.001$; one-tailed unpaired $t$ test.

ated by $5-\mathrm{HT}_{2 \mathrm{~A}}$ receptors is impaired in the absence of PSD-95, we examined the effect of SR 46349B (1 mg/kg) in another widely used animal model of psychosis, PCP-induced hyperlocomotion, which is also normalized by atypical antipsychotics such as clozapine (Gleason and Shannon, 1997; Geyer and Ellenbroek,
2003). As expected, SR46349B (1 mg/kg) normalizes PCP-induced hyperlocomotion in PSD-95 ${ }^{\text {wildtype }}$ but not PSD-95 $5^{\text {null }}$ mice (Fig. $8 D$ ). Thus, our findings are very consistent in showing that the genetic deletion of PSD-95 leads to 5- $\mathrm{HT}_{2 \mathrm{~A}}$ receptor dysfunction which in turn prevents atypical antipsychotics from being therapeutically efficacious in animal models of psychosis.

\section{Discussion}

The main finding of this study is that PSD-95 is essential for serotonin receptor function and hallucinogen and atypical antipsychotic actions in vivo. These findings suggest that in addition to its well known modulatory effect on ionotropic glutamatergic signaling, PSD-95 is required for normal metabotropic serotonin receptor function. We show that PSD-95, a modular PDZ domain-containing protein which scaffolds a wide range of proteins at postsynaptic clusters, is an important regulatory partner for both $5-\mathrm{HT}_{2 \mathrm{~A}}$ and $5-\mathrm{HT}_{2 \mathrm{C}}$ receptors in vivo. In the absence of PSD-95, the 5- $\mathrm{HT}_{2 \mathrm{~A}}$ receptor has accelerated receptor turnover kinetics and decreased targeting to the appropriate dendritic compartment, leading to a decrease in total receptor expression and a concomitant decrease in $5-\mathrm{HT}_{2 \mathrm{~A}}$-mediated signaling (p-ERK1/2 and p-GSK3 $\beta$ ) and behaviors (e.g., head-twitch response). In the absence of PSD-95, the $5-\mathrm{HT}_{2 \mathrm{C}}$ receptor exhibits a larger decrease in receptor protein expression and downstream signaling. Finally, we show that, in the absence of PSD-95, the prototypical atypical antipsychotic drug clozapine, as well as the selective $5-\mathrm{HT}_{2 \mathrm{~A}}$ antagonists M100907 and SR46349B, are unable to mediate their therapeutic effects in animal psychosis models.

\section{5- $\mathrm{HT}_{2 \mathrm{C}}$ receptors, PSD-95, and}

psychiatric disease

There is considerable evidence that $5-\mathrm{HT}_{2 \mathrm{C}}$ serotonin receptors regulate hippocampal function. Genetic evidence from $5-\mathrm{HT}_{2 \mathrm{C}}$ knock-out mice shows that long-term potentiation (LTP) is impaired in the dentate gyrus in the absence of $5-\mathrm{HT}_{2 \mathrm{C}}$ receptors (Tecott et al., 1998). $5-\mathrm{HT}_{2 \mathrm{C}}$ knock-out mice also exhibit defects in behaviors thought to be mediated by the dentate gyrus (Tecott et al., 1998) and are more susceptible to spontaneous and audiogenic seizures (Tecott et al., 1995), which are known to involve limbic recruitment (Wieraszko and Seyfried, 1993; Pereira et al., 2008).

Despite this evidence that $5-\mathrm{HT}_{2 \mathrm{C}}$ receptors modulate neuronal function, nothing is known regarding their targeting and reg- 
ulation of neuronal function. Our data concerning the $5-\mathrm{HT}_{2 \mathrm{C}}$ receptor's interaction with, and regulation by, PSD-95 suggests that the $5-\mathrm{HT}_{2 \mathrm{C}}$ receptor is present at PSD-95-enriched neuronal domains where it would be well placed to influence neuronal excitability and synaptic properties and, therefore, brain electrical activity. Although our studies focused on $5-\mathrm{HT}_{2 \mathrm{C}}$ function in the hippocampus, the potential relevance of our findings to $5-\mathrm{HT}_{2 \mathrm{C}}$ function in other brain regions is also of interest. The $5-\mathrm{HT}_{2 \mathrm{C}}$ receptor has shown promise as a target in the treatment of a number of psychiatric disorders, including in particular schizophrenia and obesity, although it has been proposed that $5-\mathrm{HT}_{2 \mathrm{C}}$ receptors may also play a role in the etiology and treatment of OCD and depression (Dunlop et al., 2005, 2006; Sard et al., 2005; Gray and Roth, 2007; Marquis et al., 2007). Thus, PSD-95 may play a role in regulating $5-\mathrm{HT}_{2 \mathrm{C}}$ function in various disease states, although further study will be needed to investigate this intriguing possibility.

\section{Implications of PSD-95 regulation of hallucinogen action}

Although it is known that hallucinogens exert their effects via activation of the 5- $\mathrm{HT}_{2 \mathrm{~A}}$ receptor (Glennon et al., 1983), the signaling processes underlying hallucinogen action are still poorly characterized. Recent evidence suggests that cortical $5-\mathrm{HT}_{2 \mathrm{~A}}$ receptors are required for hallucinogen actions, possibly by facilitating corticocortical activity (González-Maeso et al., 2007). Our data are relevant in several respects. First, our findings are consistent with the hypothesis that hallucinogens exert their effects at cortical pyramidal neuron apical dendrites. Apical dendritic activity has been implicated as forming the neural basis for cognition and consciousness (LaBerge, 2006; Laberge and Kasevich, 2007), and it is thought that corticocortical connections, which are primarily composed of synaptic contacts at apical dendrites (Spratling, 2002), are important in generating and shaping the neural activity that underlies consciousness (Tononi and Edelman, 1998). Furthermore, the primary neuro-anatomical site of expression of $5-\mathrm{HT}_{2 \mathrm{~A}}$ receptors is the apical dendrites of cortical pyramidal neurons, particularly in layer $\mathrm{V}$ pyramidal neurons (Willins et al., 1997; Jakab and GoldmanRakic, 1998). Finally, a wide range of evidence supports altered glutamatergic signaling in neocortex as playing a key role in mediating the effects of hallucinogens on consciousness (Aghajanian and Marek,

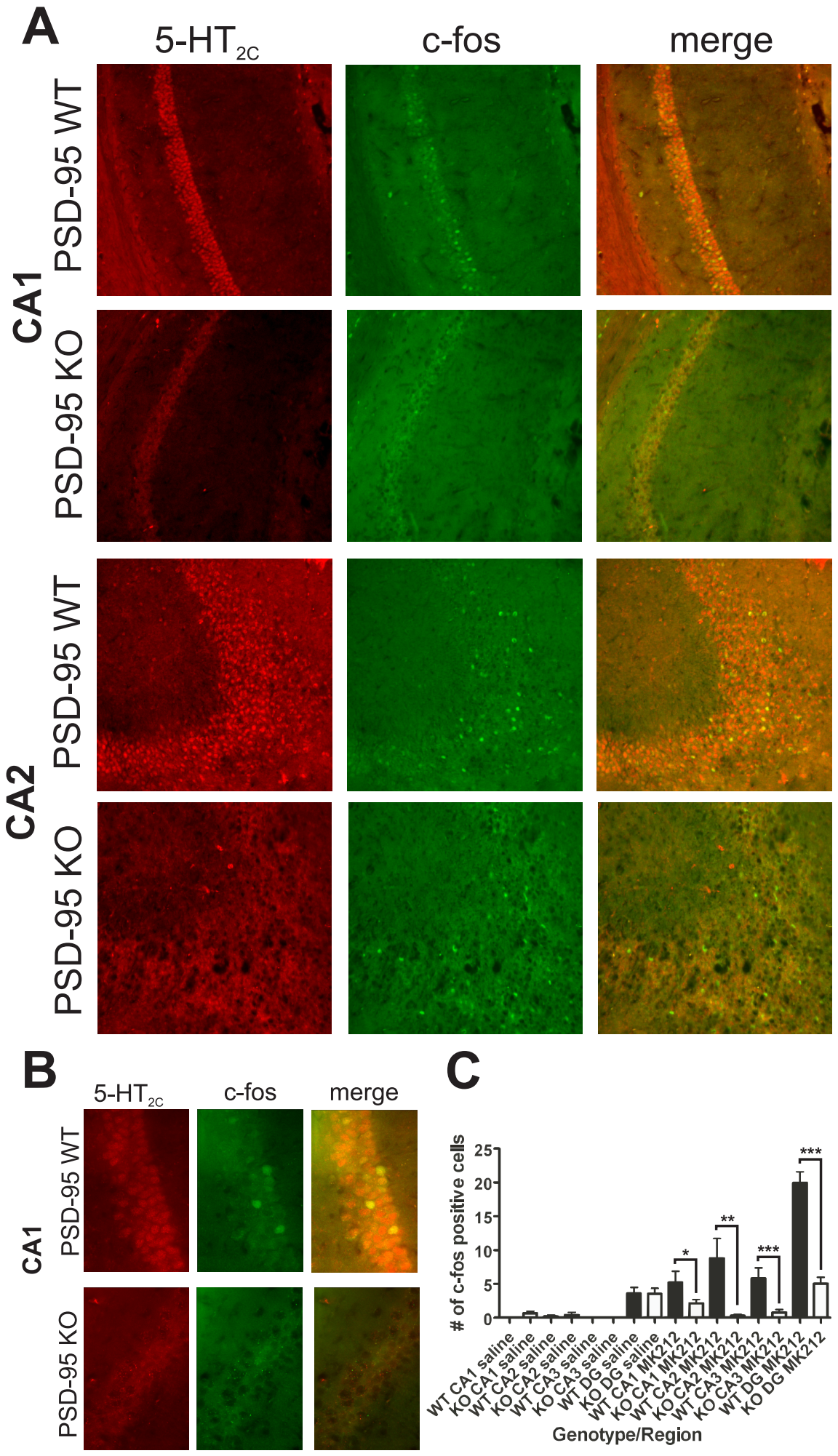

Figure 6. Deletion of PSD-95 attenuates $5-\mathrm{HT}_{2 C}$ receptor-mediated induction of c-fos. $\boldsymbol{A}, 5-\mathrm{HT}_{2 \mathrm{C}}$ and c-fos double-label immunochemistry in the hippocampus of PSD-95 ${ }^{\text {wildtype }}$ and PSD-95 ${ }^{\text {null }}$ mice after MK-212 treatment ( $N=3$ littermate pairs). Representative images of CA1 and CA2 are shown. There are fewer c-fos-positive cells in the PSD-95 ${ }^{\text {null }}$ mice treated with MK-212 in both CA1 and CA2. B, Higher magnification image of CA1 to examine colocalization of 5- $\mathrm{HT}_{2 \mathrm{C}}$ receptors and $\mathrm{C}-\mathrm{fos}$. $5-\mathrm{HT}_{2 \mathrm{C}}$ receptor colocalizes with $\mathrm{C}-\mathrm{fos}$, suggesting that $5-\mathrm{HT}_{2 \mathrm{C}}$ is inducing this IEG directly, rather than indirectly in surrounding neurons. $\boldsymbol{C}$, Analysis of c-fos induction was performed by counting the number of c-fos-positive cells in CA1, CA2, CA3, and DG. Data are presented as the mean number of c-fos-positive cells \pm the SEM. There is a significant reduction in c-fos-positive cells in the absence of PSD-95 in all four regions that were measured. c-fos counts were performed separately in the hippocampus of each hemisphere ( 2 values for each section analyzed). Every seventh section was analyzed, for a total of six sections per animal. * $p<$ $0.05,{ }^{* *} p<0.01,{ }^{* * *} p<0.001$; one-tailed unpaired $t$ test. 

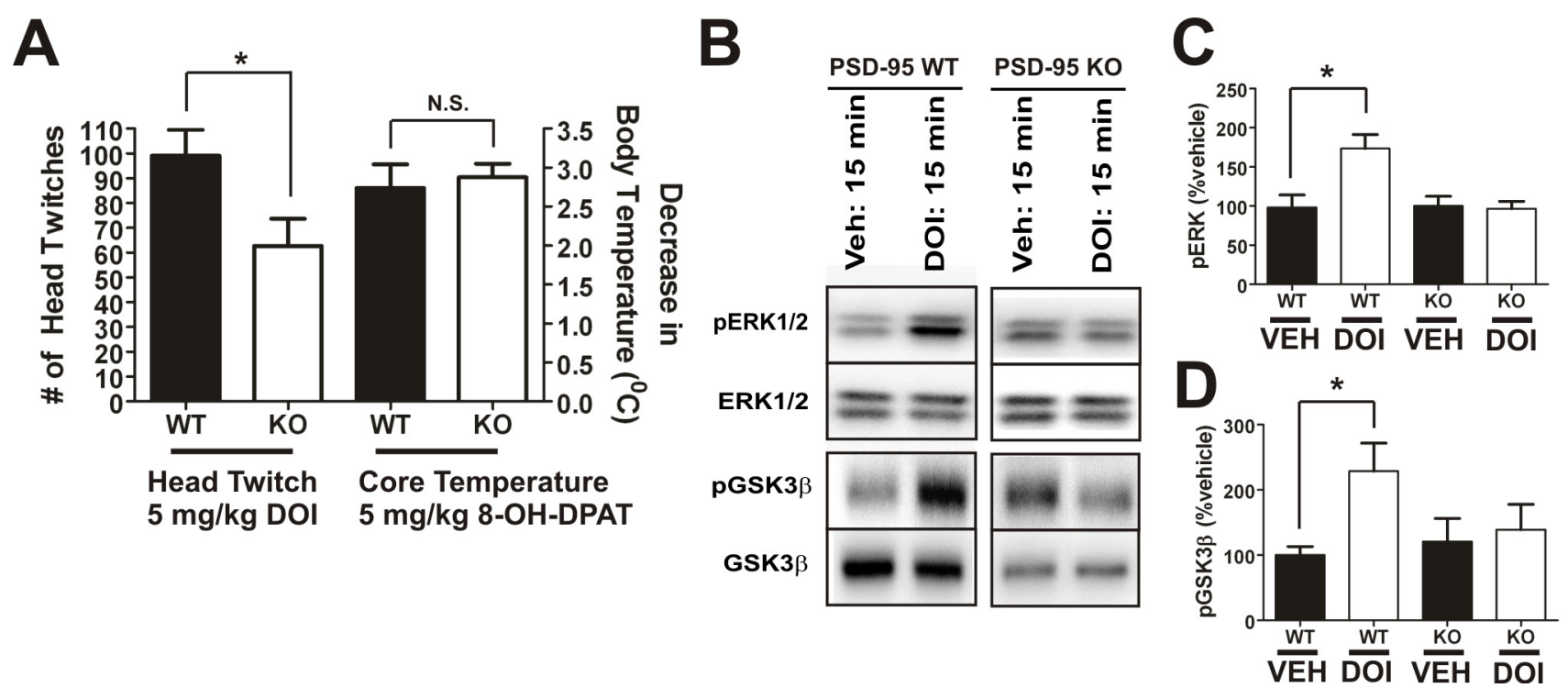

Figure 7. $5-\mathrm{HT}_{2 \mathrm{~A}}$-mediated head-twitch behavior is attenuated in PSD-95 null mice. $A, 5-\mathrm{HT}_{2 \mathrm{~A}}$-mediated head-twitch response after intraperitoneal injection of $5 \mathrm{mg} / \mathrm{kg} \mathrm{DOI}(\mathrm{N}=11$ littermate pairs) and $5-\mathrm{HT}_{1 \mathrm{~A}}$-mediated hypothermic response after intraperitoneal injection of $5 \mathrm{mg} / \mathrm{kg} 8-\mathrm{OH}-\mathrm{DPAT}$ ( $\mathrm{N}=12$ littermate pairs). There is a significant decrease in DOI-induced head-twitch in PSD-95 ${ }^{\text {null }}$ mice, in contrast with the magnitude of the decrease in core body temperature induced by 8-OH-DPAT, which is the same in both PSD-95 wildtype and PSD-95 ${ }^{\text {null }}$ mice. $B-D$, Western blot and associated quantification for $\mathrm{p}$-ERK1/2, ERK1/2, p-GSK3 $\beta$, and GSK3 $\beta 15 \mathrm{~min}$ after intraperitoneal injection of vehicle or DOI ( $N=4-5$ littermate pairs). DOI induces pERK1/2 and pGSK3 $\beta$ in wild-type, but not null, mice. For quantification, p-ERK1/2 and p-GSK3 $\beta$ were normalized to ERK1/2 and GSK3 $\beta$, respectively. Data are given as means \pm the SEM; ${ }^{*} p<0.05{ }^{* *} p<0.01$, ${ }^{* * *} p<$ 0.001 ; one-tailed unpaired $t$ test.
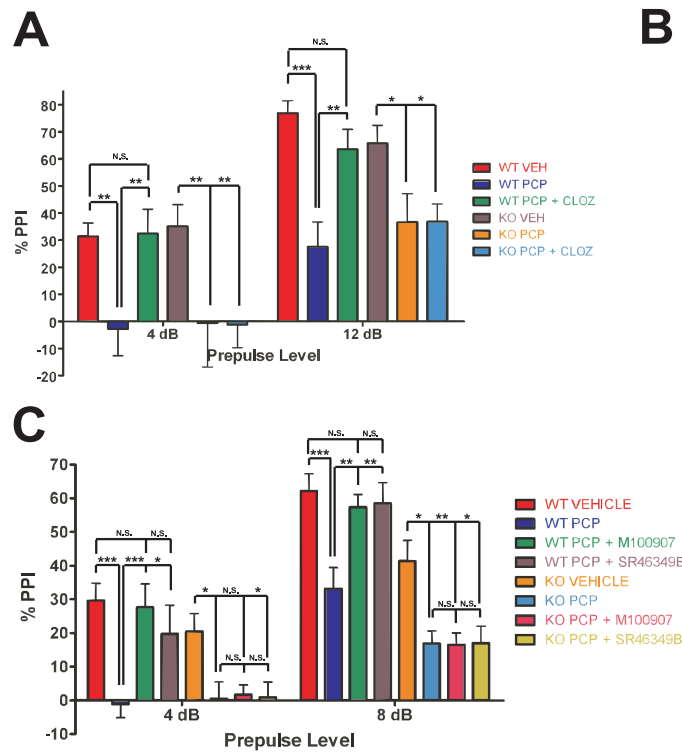

B

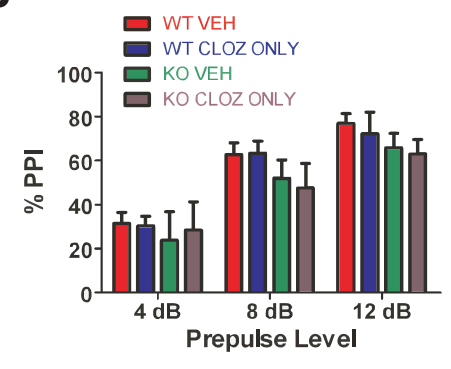

D

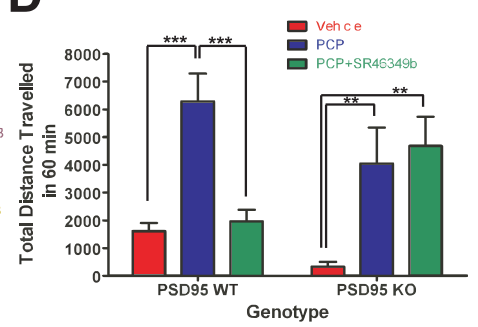

Figure 8. The antipsychotic-like efficacy of atypical antipsychotics is lost in PSD-95 ${ }^{\text {null }}$ mice. At the two prepulses shown, 4 and

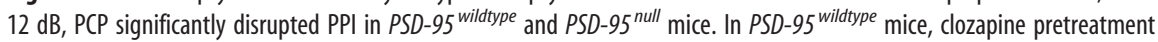
normalized the disruption of PPI by PCP at both 4 and $12 \mathrm{~dB}\left(N=6\right.$ littermate pairs). In contrast, in PSD-95 ${ }^{\text {null }}$ mice, clozapine had no antipsychotic-like effect. $B$, PPI after treatment with clozapine alone ( $N=6$ littermate pairs). Clozapine $(0.5 \mathrm{mg} / \mathrm{kg}) \mathrm{had}$ no effect on PPI compared with vehicle. C, PPI in PSD-95 wildtype and PSD-95 ${ }^{\text {null }}$ mice after injection of vehicle, $6.0 \mathrm{mg} / \mathrm{kg} P C P, 0.5$ $\mathrm{mg} / \mathrm{kg}$ M100907 plus $6.0 \mathrm{mg} / \mathrm{kg}$ PCP, or $1.0 \mathrm{mg} / \mathrm{kg}$ SR46349B plus $6.0 \mathrm{mg} / \mathrm{kg} P$ PP. PCP significantly disrupted PPI in PSD-95 wildtype and PSD-95 ${ }^{\text {null }}$ mice at 4 and $8 \mathrm{~dB}(N=12)$. In PSD-95 wildtype mice, M100907 or SR46349B pretreatment normalized the disruption of PPI by PCP at 4 and $8 \mathrm{~dB}$, whereas in PSD-95 ${ }^{\text {null }}$ mice, they had no antipsychotic-like effect. $D$, Locomotion after vehicle, $6.0 \mathrm{mg} / \mathrm{kg} \mathrm{PCP}$, and $1.0 \mathrm{mg} / \mathrm{kg}$ SR46349B plus $6.0 \mathrm{mg} / \mathrm{kg} P C P$ in PSD-95 ${ }^{\text {wildtype }}$ and PSD-95 ${ }^{\text {null }}$ mice $(N=12)$. SR46349B normalizes PCP-induced hyperlocomotion in PSD-95 wildtype mice only. Data are given as means \pm the SEM; * $p<0.05$, ${ }^{* *} p<$ $0.01,{ }^{* * *} p<0.001$; two-way repeated-measures ANOVA followed by Bonferroni post-tests.

1999). Importantly, our studies demonstrate that the overall expression and apical dendritic targeting of $5-\mathrm{HT}_{2 \mathrm{~A}}$ receptors to postsynaptic densities is significantly impaired in cortical neurons prepared from PSD-95 ${ }^{\text {null }}$ mice. Also, DOI is unable to in- duce p-ERK1/2 and p-GSK3 $\beta$ in PSD$95^{\text {null }}$ mice. Not surprisingly, DOIinduced head-twitch behavior, the behavioral correlate of hallucinogen action, is also reduced. Moreover, we found that the reintroduction of PSD-95 into PSD-95 ${ }^{\text {null }}$ neurons rescues both the deficient expression and targeting phenotype.

Our data provide a mechanism whereby $5-\mathrm{HT}_{2 \mathrm{~A}}$ receptors can be targeted to a cortical, postsynaptic site of action and trafficked appropriately once they have arrived. In fact, our studies have provided the first candidate subcellular locus for hallucinogen action, the PSD-95-scaffolded macromolecular signaling complex of cortical neurons. Given the accumulating evidence that hallucinogenic action involves alterations in synaptic activity, our data further suggest the possibility that hallucinogens may exert their actions via PSD-95-mediated interactions with glutamatergic signaling complexes downstream of $5-\mathrm{HT}_{2 \mathrm{~A}}$ receptor activation.

Atypical antipsychotics are ineffective in the absence of PSD-95

It has been known for some time that PCP, a noncompetitive NMDA receptor antagonist, induces psychotic and "deficit" states that are nearly indistinguishable from the positive and negative symptoms of schizophrenia (Jentsch and Roth, 1999; Olney et al., 1999; Javitt, 2004). Furthermore, clozapine and other drugs with potent $5-\mathrm{HT}_{2 \mathrm{~A}}$ inverse agonist actions ameliorate PCP-induced PPI deficits (Carlsson et al., 1999; Yamada et al., 1999; Geyer et al., 2001; Linn et al., 2003). 
Finally, genetic deletion of PSD-95 or deletion of one of the PDZ domains results in abnormalities in LTP, a phenotype related to glutamatergic dysfunction (Migaud et al., 1998; Yao et al., 2004). Together with our data, the evidence suggest that one of the key subcellular locations at which the functional interplay between $5-\mathrm{HT}_{2 \mathrm{~A}}$ receptors and glutamatergic signaling takes place is the PSD-95-scaffolded postsynaptic density.

Since, in the absence of PSD-95, glutamatergic signaling is abnormal, and $5-\mathrm{HT}_{2 \mathrm{~A}}$ receptors are mistargeted and mistrafficked, we predicted that there may be abnormalities in the ability of clozapine and selective $5-\mathrm{HT}_{2 \mathrm{~A}}$ antagonists to alleviate PCPinduced psychotic-like behaviors in mice. We found that clozapine, M100907, or SR46349B treatment, which reduced PCPinduced deficits of PPI in PSD-95 $5^{\text {wildtype }}$ mice, was completely ineffective in $P S D-95^{\text {null }}$ mice. The dramatically impaired antipsychotic-like action of the aforementioned atypical antipsychotics in the PSD-95 ${ }^{\text {null }}$ mice is likely attributable to the combined abnormalities in $5-\mathrm{HT}_{2 \mathrm{~A}}$ and $5-\mathrm{HT}_{2 \mathrm{C}}$ receptor functionboth of which have long been thought to be essential for their unique benefits (Roth et al., 2004a). Our studies clearly implicate the $5-\mathrm{HT}_{2 \mathrm{~A}}$ dysfunction that results in the absence of PSD-95 as being responsible for the lack of atypical antipsychotic efficacy in PSD-95 ${ }^{\text {null }}$ mice.

\section{Conclusions}

In this study, we demonstrate that PSD-95, in addition to its well known role in scaffolding glutamatergic signaling complexes and facilitating neuronal plasticity, potently regulates neuronal metabotropic serotonin receptor targeting, trafficking, and signaling in vivo. Furthermore, we show that the absence of PSD-95 results in abnormal downstream signaling for both $5-\mathrm{HT}_{2 \mathrm{~A}}$ receptors and $5-\mathrm{HT}_{2 \mathrm{C}}$ receptors, both of which are important therapeutic targets for a number of psychiatric diseases. We also show that the $5-\mathrm{HT}_{2 \mathrm{~A}}$ dysfunction has profound consequences with regards to the treatment of psychotic-like states in relevant animal models. Our findings demonstrate an unexpectedly profound role for $\mathrm{PSD}-95$ in regulating $5-\mathrm{HT}_{2 \mathrm{~A}}$ and $5-\mathrm{HT}_{2 \mathrm{C}}$ receptor function and the behavioral responses to drugs acting at these receptors. These results imply that PSD-95 may serve as a scaffold to integrate information between ionotropic and metabotropic neurotransmission at postsynaptic densities.

\section{References}

Aghajanian GK, Marek GJ (1999) Serotonin and hallucinogens. Neuropsychopharmacology 21:16S-23S.

Ahlemeyer B, Baumgart-Vogt E (2005) Optimized protocols for the simultaneous preparation of primary neuronal cultures of the neocortex, hippocampus and cerebellum from individual newborn (P0.5) C57BL/6J mice. J Neurosci Methods 149:110-120.

Beaulieu JM, Marion S, Rodriguiz RM, Medvedev IO, Sotnikova TD, Ghisi V, Wetsel WC, Lefkowitz RJ, Gainetdinov RR, Caron MG (2008) A betaarrestin 2 signaling complex mediates lithium action on behavior. Cell 132:125-136

Bécamel C, Alonso G, Galéotti N, Demey E, Jouin P, Ullmer C, Dumuis A, Bockaert J, Marin P (2002) Synaptic multiprotein complexes associated with 5-HT(2C) receptors: a proteomic approach. EMBO J 21:2332-2342.

Bécamel C, Gavarini S, Chanrion B, Alonso G, Galéotti N, Dumuis A, Bockaert J, Marin P (2004) The serotonin 5-HT2A and 5-HT2C receptors interact with specific sets of PDZ proteins. J Biol Chem 279:20257-20266.

Berg KA, Cropper JD, Niswender CM, Sanders-Bush E, Emeson RB, Clarke WP (2001) RNA-editing of the 5-HT(2C) receptor alters agonistreceptor-effector coupling specificity. Br J Pharmacol 134:386-392.

Berger M, Gray JA, Roth BL (2009) The expanded biology of serotonin receptors. Annu Rev Med 60:355-366.
Burns CM, Chu H, Rueter SM, Hutchinson LK, Canton H, Sanders-Bush E, Emeson RB (1997) Regulation of serotonin-2C receptor G-protein coupling by RNA editing. Nature 387:303-308.

Caceres A, Banker G, Steward O, Binder L, Payne M (1984) MAP2 is localized to the dendrites of hippocampal neurons which develop in culture. Brain Res 315:314-318.

Campbell BM, Merchant KM (2003) Serotonin 2C receptors within the basolateral amygdala induce acute fear-like responses in an open-field environment. Brain Res 993:1-9.

Carlsson ML, Martin P, Nilsson M, Sorensen SM, Carlsson A, Waters S, Waters N (1999) The 5-HT2A receptor antagonist M100907 is more effective in counteracting NMDA antagonist- than dopamine agonistinduced hyperactivity in mice. J Neural Transm 106:123-129.

Chaudhuri A (1997) Neural activity mapping with inducible transcription factors. Neuroreport 8:v-ix.

Chen L, Chetkovich DM, Petralia RS, Sweeney NT, Kawasaki Y, Wenthold RJ, Bredt DS, Nicoll RA (2000) Stargazin regulates synaptic targeting of AMPA receptors by two distinct mechanisms. Nature 408:936-943.

Clemett DA, Punhani T, Duxon MS, Blackburn TP, Fone KC (2000) Immunohistochemical localisation of the 5 -HT2C receptor protein in the rat CNS. Neuropharmacology 39:123-132.

Du Y, Davisson MT, Kafadar K, Gardiner K (2006) A-to-I pre-mRNA editing of the serotonin $2 \mathrm{C}$ receptor: comparisons among inbred mouse strains. Gene 382:39-46.

Dunlop J, Sabb AL, Mazandarani H, Zhang J, Kalgaonker S, Shukhina E, Sukoff S, Vogel RL, Stack G, Schechter L, Harrison BL, RosenzweigLipson S (2005) WAY-163909 [(7bR, 10aR)-1,2,3,4,8,9,10,10aoctahydro-7bH-cyclopenta-[b][1,4] diazepino[6,7,1h i] indole], a novel 5-hydroxytryptamine $2 \mathrm{C}$ receptor-selective agonist with anorectic activity. J Pharmacol Exp Ther 313:862-869.

Dunlop J, Marquis KL, Lim HK, Leung L, Kao J, Cheesman C, RosenzweigLipson S (2006) Pharmacological profile of the 5-HT(2C) receptor agonist WAY-163909; therapeutic potential in multiple indications. CNS Drug Rev 12:167-177.

Ehrlich I, Malinow R (2004) Postsynaptic density 95 controls AMPA receptor incorporation during long-term potentiation and experience-driven synaptic plasticity. J Neurosci 24:916-927.

Gavarini S, Bécamel C, Altier C, Lory P, Poncet J, Wijnholds J, Bockaert J, Marin P (2006) Opposite effects of PSD-95 and MPP3 PDZ proteins on serotonin 5-hydroxytryptamine2C receptor desensitization and membrane stability. Mol Biol Cell 17:4619-4631.

Geyer MA, Ellenbroek B (2003) Animal behavior models of the mechanisms underlying antipsychotic atypicality. Prog Neuropsychopharmacol Biol Psychiatry 27:1071-1079.

Geyer MA, Krebs-Thomson K, Braff DL, Swerdlow NR (2001) Pharmacological studies of prepulse inhibition models of sensorimotor gating deficits in schizophrenia: a decade in review. Psychopharmacology (Berl) 156:117-154.

Gleason SD, Shannon HE (1997) Blockade of phencyclidine-induced hyperlocomotion by olanzapine, clozapine and serotonin receptor subtype selective antagonists in mice. Psychopharmacology (Berl) 129:79-84.

Glennon RA, Young R, Rosecrans JA (1983) Antagonism of the effects of the hallucinogen DOM and the purported 5-HT agonist quipazine by 5-HT2 antagonists. Eur J Pharmacol 91:189-196.

Glennon RA, Titeler M, McKenney JD (1984) Evidence for 5-HT2 involvement in the mechanism of action of hallucinogenic agents. Life Sci 35:2505-2511.

González-Maeso J, Yuen T, Ebersole BJ, Wurmbach E, Lira A, Zhou M, Weisstaub N, Hen R, Gingrich JA, Sealfon SC (2003) Transcriptome fingerprints distinguish hallucinogenic and nonhallucinogenic 5-hydroxytryptamine $2 \mathrm{~A}$ receptor agonist effects in mouse somatosensory cortex. J Neurosci 23:8836-8843.

González-Maeso J, Weisstaub NV, Zhou M, Chan P, Ivic L, Ang R, Lira A, Bradley-Moore M, Ge Y, Zhou Q, Sealfon SC, Gingrich JA (2007) Hallucinogens recruit specific cortical 5-HT(2A) receptor-mediated signaling pathways to affect behavior. Neuron 53:439-452.

Göoz M, Göoz P, Luttrell LM, Raymond JR (2006) 5-HT2A receptor induces ERK phosphorylation and proliferation through ADAM-17 tumor necrosis factor-alpha-converting enzyme (TACE) activation and heparin-bound epidermal growth factor-like growth factor (HB-EGF) shedding in mesangial cells. J Biol Chem 281:21004-21012. 
Gray JA, Roth BL (2007) The pipeline and future of drug development in schizophrenia. Mol Psychiatry 12:904-922.

Greene EL, Houghton O, Collinsworth G, Garnovskaya MN, Nagai T, Sajjad T, Bheemanathini V, Grewal JS, Paul RV, Raymond JR (2000) 5-HT(2A) receptors stimulate mitogen-activated protein kinase via $\mathrm{H}(2) \mathrm{O}(2)$ generation in rat renal mesangial cells. Am J Physiol Renal Physiol 278:F650-F658.

Hershenson MB, Chao TS, Abe MK, Gomes I, Kelleher MD, Solway J, Rosner MR (1995) Histamine antagonizes serotonin and growth factorinduced mitogen-activated protein kinase activation in bovine tracheal smooth muscle cells. J Biol Chem 270:19908-19913.

Imamura F, Maeda S, Doi T, Fujiyoshi Y (2002) Ligand binding of the second PDZ domain regulates clustering of PSD-95 with the Kv1.4 potassium channel. J Biol Chem 277:3640-3646.

Jakab RL, Goldman-Rakic PS (1998) 5-Hydroxytryptamine2A serotonin receptors in the primate cerebral cortex: possible site of action of hallucinogenic and antipsychotic drugs in pyramidal cell apical dendrites. Proc Natl Acad Sci U S A 95:735-740.

Javitt DC (2004) Glutamate as a therapeutic target in psychiatric disorders. Mol Psychiatry 9:984-997, 979.

Jentsch JD, Roth RH (1999) The neuropsychopharmacology of phencyclidine: from NMDA receptor hypofunction to the dopamine hypothesis of schizophrenia. Neuropsychopharmacology 20:201-225.

Johnson-Farley NN, Kertesy SB, Dubyak GR, Cowen DS (2005) Enhanced activation of Akt and extracellular-regulated kinase pathways by simultaneous occupancy of Gq-coupled 5-HT2A receptors and Gs-coupled 5-HT7A receptors in PC12 cells. J Neurochem 92:72-82.

Kim S, Burette A, Chung HS, Kwon SK, Woo J, Lee HW, Kim K, Kim H, Weinberg RJ, Kim E (2006) NGL family PSD-95-interacting adhesion molecules regulate excitatory synapse formation. Nat Neurosci 9:1294-1301.

LaBerge D (2006) Apical dendrite activity in cognition and consciousness. Conscious Cogn 15:235-257.

Laberge D, Kasevich R (2007) The apical dendrite theory of consciousness. Neural Netw 20:1004-1020.

Li X, Zhu W, Roh MS, Friedman AB, Rosborough K, Jope RS (2004) In vivo regulation of glycogen synthase kinase-3beta (GSK3beta) by serotonergic activity in mouse brain. Neuropsychopharmacology 29:1426-1431.

Linn GS, Javitt DC (2001) Phencyclidine (PCP)-induced deficits of prepulse inhibition in monkeys. Neuroreport 12:117-120.

Linn GS, Negi SS, Gerum SV, Javitt DC (2003) Reversal of phencyclidineinduced prepulse inhibition deficits by clozapine in monkeys. Psychopharmacology (Berl) 169:234-239.

Lo RK, Wong YH (2006) Transcriptional activation of c-Fos by constitutively active Galpha(16)QL through a STAT1-dependent pathway. Cell Signal 18:2143-2153.

Lois C, Hong EJ, Pease S, Brown EJ, Baltimore D (2002) Germline transmission and tissue-specific expression of transgenes delivered by lentiviral vectors. Science 295:868-872.

López-Giménez JF, Tecott LH, Palacios JM, Mengod G, Vilaró MT (2002) Serotonin 5- HT (2C) receptor knockout mice: autoradiographic analysis of multiple serotonin receptors. J Neurosci Res 67:69-85.

Marquis KL, Sabb AL, Logue SF, Brennan JA, Piesla MJ, Comery TA, Grauer SM, Ashby CR Jr, Nguyen HQ, Dawson LA, Barrett JE, Stack G, Meltzer HY, Harrison BL, Rosenzweig-Lipson S (2007) WAY-163909 [(7bR,10aR)-1,2,3,4,8,9,10,10a-octahydro-7bH-cyclopenta-[b] [1,4] diazepino[6,7,1hi]indole]: a novel 5-hydroxytryptamine 2C receptorselective agonist with preclinical antipsychotic-like activity. J Pharmacol Exp Ther 320:486-496.

Martin KF, Phillips I, Hearson M, Prow MR, Heal DJ (1992) Characterization of 8-OH-DPAT-induced hypothermia in mice as a 5-HT1A autoreceptor response and its evaluation as a model to selectively identify antidepressants. Br J Pharmacol 107:15-21.

Meltzer HY, Matsubara S, Lee JC (1989) Classification of typical and atypical antipsychotic drugs on the basis of dopamine D-1, D-2 and serotonin2 pKi values. J Pharmacol Exp Ther 251:238-246.

Meltzer HY, Arvanitis L, Bauer D, Rein W (2004) Placebo-controlled evaluation of four novel compounds for the treatment of schizophrenia and schizoaffective disorder. Am J Psychiatry 161:975-984.

Migaud M, Charlesworth P, Dempster M, Webster LC, Watabe AM, Makhinson M, He Y, Ramsay MF, Morris RG, Morrison JH, O’Dell TJ, Grant SG
(1998) Enhanced long-term potentiation and impaired learning in mice with mutant postsynaptic density-95 protein. Nature 396:433-439.

Molineaux SM, Jessell TM, Axel R, Julius D (1989) 5-HT1c receptor is a prominent serotonin receptor subtype in the central nervous system. Proc Natl Acad Sci U S A 86:6793-6797.

Nichols CD, Sanders-Bush E (2002) A single dose of lysergic acid diethylamide influences gene expression patterns within the mammalian brain. Neuropsychopharmacology 26:634-642.

Nichols DE (2004) Hallucinogens. Pharmacol Ther 101:131-181.

Nicoll RA, Tomita S, Bredt DS (2006) Auxiliary subunits assist AMPA-type glutamate receptors. Science 311:1253-1256.

Niswender CM, Copeland SC, Herrick-Davis K, Emeson RB, Sanders-Bush E (1999) RNA editing of the human serotonin 5-hydroxytryptamine 2C receptor silences constitutive activity. J Biol Chem 274:9472-9478.

Olney JW, Newcomer JW, Farber NB (1999) NMDA receptor hypofunction model of schizophrenia. J Psychiatr Res 33:523-533.

Pereira MG, Gitaí DL, Paçó-Larson ML, Pesquero JB, Garcia-Cairasco N, Costa-Neto CM (2008) Modulation of B1 and B2 kinin receptors expression levels in the hippocampus of rats after audiogenic kindling and with limbic recruitment, a model of temporal lobe epilepsy. Int Immunopharmacol 8:200-205.

Pinto W, Battaglia G (1994) Comparative recovery kinetics of 5-hydroxytryptamine $1 \mathrm{~A}, 1 \mathrm{~B}$, and $2 \mathrm{~A}$ receptor subtypes in rat cortex after receptor inactivation: evidence for differences in receptor production and degradation. Mol Pharmacol 46:1111-1119.

Price RD, Sanders-Bush E (2000) RNA editing of the human serotonin 5-HT(2C) receptor delays agonist-stimulated calcium release. Mol Pharmacol 58:859-862.

Quinn JC, Johnson-Farley NN, Yoon J, Cowen DS (2002) Activation of extracellular-regulated kinase by 5 -hydroxytryptamine $(2 \mathrm{~A})$ receptors in PC12 cells is protein kinase $\mathrm{C}$-independent and requires calmodulin and tyrosine kinases. J Pharmacol Exp Ther 303:746-752.

Rauser L, Savage JE, Meltzer HY, Roth BL (2001) Inverse agonist actions of typical and atypical antipsychotic drugs at the human 5-hydroxytryptamine(2C) receptor. J Pharmacol Exp Ther 299:83-89.

Roth BL, Baner K, Westkaemper R, Siebert D, Rice KC, Steinberg S, Ernsberger P, Rothman RB (2002) Salvinorin A: a potent naturally occurring nonnitrogenous kappa opioid selective agonist. Proc Natl Acad Sci U S A 99:11934-11939.

Roth BL, Sheffler DJ, Kroeze WK (2004a) Magic shotguns versus magic bullets: selectively non-selective drugs for mood disorders and schizophrenia. Nat Rev Drug Discov 3:353-359.

Roth BL, Lopez E, Beischel S, Westkaemper RB, Evans JM (2004b) Screening the receptorome to discover the molecular targets for plant-derived psychoactive compounds: a novel approach for CNS drug discovery. Pharmacol Ther 102:99-110.

Sard H, Kumaran G, Morency C, Roth BL, Toth BA, He P, Shuster L (2005) SAR of psilocybin analogs: discovery of a selective 5-HT 2C agonist. Bioorg Med Chem Lett 15:4555-4559.

Schlüter OM, Xu W, Malenka RC (2006) Alternative N-terminal domains of PSD-95 and SAP97 govern activity-dependent regulation of synaptic AMPA receptor function. Neuron 51:99-111.

Schmid CL, Raehal KM, Bohn LM (2008) Agonist-directed signaling of the serotonin 2A receptor depends on beta-arrestin-2 interactions in vivo. Proc Natl Acad Sci U S A 105:1079-1084.

Sheng M, Kim MJ (2002) Postsynaptic signaling and plasticity mechanisms. Science 298:776-780

Spratling MW (2002) Cortical region interactions and the functional role of apical dendrites. Behav Cogn Neurosci Rev 1:219-228.

Tecott LH, Sun LM, Akana SF, Strack AM, Lowenstein DH, Dallman MF, Julius D (1995) Eating disorder and epilepsy in mice lacking 5-HT2c serotonin receptors. Nature 374:542-546.

Tecott LH, Logue SF, Wehner JM, Kauer JA (1998) Perturbed dentate gyrus function in serotonin 5-HT2C receptor mutant mice. Proc Natl Acad Sci U S A 95:15026-15031.

Thomsen WJ, Grottick AJ, Menzaghi F, Reyes-Saldana H, Espitia S, Yuskin D, Whelan K, Martin M, Morgan M, Chen W, Al-Shamma H, Smith B, Chalmers D, Behan D (2008) Lorcaserin, a novel selective human 5-HT2C agonist: in vitro and in vivo pharmacological characterization. J Pharmacol Exp Ther 325:577-587.

Tononi G, Edelman GM (1998) Consciousness and complexity. Science 282:1846-1851. 
Urban JD, Clarke WP, von Zastrow M, Nichols DE, Kobilka B, Weinstein H, Javitch JA, Roth BL, Christopoulos A, Sexton PM, Miller KJ, Spedding M, Mailman RB (2007) Functional selectivity and classical concepts of quantitative pharmacology. J Pharmacol Exp Ther 320:1-13.

Varty GB, Bakshi VP, Geyer MA (1999) M100907, a serotonin 5-HT2A receptor antagonist and putative antipsychotic, blocks dizocilpine-induced prepulse inhibition deficits in Sprague-Dawley and Wistar rats. Neuropsychopharmacology 20:311-321.

Wieraszko A, Seyfried TN (1993) Influence of audiogenic seizures on synaptic facilitation in mouse hippocampal slices is mediated by N-methylD-aspartate receptor. Epilepsia 34:979-984.

Willins DL, Deutch AY, Roth BL (1997) Serotonin 5-HT2A receptors are expressed on pyramidal cells and interneurons in the rat cortex. Synapse 27:79-82.

Xia Z, Gray JA, Compton-Toth BA, Roth BL (2003a) A direct interaction of
PSD-95 with 5-HT2A serotonin receptors regulates receptor trafficking and signal transduction. J Biol Chem 278:21901-21908.

Xia Z, Hufeisen SJ, Gray JA, Roth BL (2003b) The PDZ-binding domain is essential for the dendritic targeting of 5-HT2A serotonin receptors in cortical pyramidal neurons in vitro. Neuroscience 122:907-920.

Xu W, Schlüter OM, Steiner P, Czervionke BL, Sabatini B, Malenka RC (2008) Molecular dissociation of the role of PSD-95 in regulating synaptic strength and LTD. Neuron 57:248-262.

Yamada S, Harano M, Annoh N, Nakamura K, Tanaka M (1999) Involvement of serotonin $2 \mathrm{~A}$ receptors in phencyclidine-induced disruption of prepulse inhibition of the acoustic startle in rats. Biol Psychiatry 46:832-838.

Yao WD, Gainetdinov RR, Arbuckle MI, Sotnikova TD, Cyr M, Beaulieu JM, Torres GE, Grant SG, Caron MG (2004) Identification of PSD-95 as a regulator of dopamine-mediated synaptic and behavioral plasticity. Neuron 41:625-638. 